\title{
DISPOSIÇÃO DE PAGAR POR ALIMENTOS SEGUROS: O CASO DOS HORTIFRUTÍCOLAS SEM RESÍDUOS DE AGROTÓXICOS
}

\author{
CARLOS MAGNO MENDES
}

Bacharel em Ciências Econômicas

Orientadora: Profa. Dra. ZILDA PAES DE BARROS MATTOS

Tese apresentada à Escola Superior de Agricultura "Luiz de Queiroz", Universidade de São Paulo, para obtenção do Título de Doutor em Ciências, Área de Concentração: Economia Aplicada.

P I R A C I C A B A

Estado de São Paulo - Brasil

Outubro - 2002 


\section{ERRATA}

\begin{tabular}{|c|c|c|c|c|}
\hline p. & item & linha & onde se lê & Leia-se \\
\hline 41 & 4.1 & décima segunda & $\begin{array}{l}\text {.. dos entrevistados, } 217 \\
\text { eram do sexo feminino e } \\
97 \text { eram do sexo } \\
\text { masculino... }\end{array}$ & $\begin{array}{l}\text {... dos entrevistados, } 216 \text { eram do } \\
\text { sexo feminino e } 98 \text { eram do sexo } \\
\text { masculino... }\end{array}$ \\
\hline 43 & 4.1 & sexta & $\begin{array}{l}\ldots \text { de entrevistados }(271) \text {, } \\
\text { ou }(87 \%) \text { da amostra ... }\end{array}$ & $\begin{array}{l}\ldots \text { de entrevistados (276) ou } \\
(88 \%) \text { da amostra } \ldots\end{array}$ \\
\hline 43 & 4.1 & oitava & $\begin{array}{l}\text {.. } 229 \text { entrevistados }(73 \%) \\
\text { escolheram ... }\end{array}$ & $\begin{array}{l}\ldots \quad 227 \text { entrevistados }(72 \%) \\
\text { escolheram ... }\end{array}$ \\
\hline 43 & 4.1 & dezenove & $\begin{array}{l}\ldots \quad \text { apenas } 14 \% \text { dos } \\
\text { entrevistados } \ldots\end{array}$ & $\begin{array}{l}\ldots \quad \text { apenas } \\
\text { entrevistados... }\end{array}$ \\
\hline 43 & 4.1 & $\begin{array}{l}\text { vigésima } \\
\text { segunda }\end{array}$ & $\begin{array}{l}\ldots \text { aparência do produto } \\
(52 \%) \text {, valor alimentar } \\
(43 \%) \text {, preço }(39 \%) \text { e } \\
\text { presença de conservantes e } \\
\text { aditivos }(10 \%) \ldots\end{array}$ & $\begin{array}{l}\text {... aparência do produto }(53 \%) \text {, } \\
\text { valor alimentar }(44 \%) \text {, preço } \\
(38 \%) \text { e presença de conservantes } \\
\text { e aditivos }(9 \%) \ldots\end{array}$ \\
\hline 44 & 4.1 & quarta & $\begin{array}{l}\text { Apenas } \quad 13 \% \quad \text { dos } \\
\text { entrevistados } \ldots\end{array}$ & Apenas $12 \%$ dos entrevistados ... \\
\hline 45 & 4.1 & sexta & $\begin{array}{l}\text {... doença crônica em casa } \\
\text { e } 35 \% \text { afirmaram fazer ... }\end{array}$ & $\begin{array}{l}\text {... doença crônica em casa e } 34 \% \\
\text { afirmaram fazer ... }\end{array}$ \\
\hline 44 & 4.1 & décima segunda & $\begin{array}{l}\ldots \text { de produtores, } 82 \\
\text { pessoas responderam ... }\end{array}$ & $\begin{array}{l}\ldots \text { de produtores, } 81 \text { pessoas } \\
\text { responderam ... }\end{array}$ \\
\hline 44 & 4.1 & décima quarta & $\begin{array}{l}\text {... com respectivamente } 45 \\
\text { e } 44 \text { entrevistados ... }\end{array}$ & $\begin{array}{l}\text {... com respectivamente } 46 \text { e } 44 \\
\text { entrevistados ... }\end{array}$ \\
\hline 47 & 4.2 & sexta & $\begin{array}{l}\text { efeito marginal: }-0,15775 \mathrm{e} \\
\text { estatística t:-3,142 }\end{array}$ & $\begin{array}{ll}\text { efeito marginal: } & -0,12758 \quad \mathrm{e} \\
\text { estatística t:-2,361 } & \end{array}$ \\
\hline 47 & 4.2 & $\begin{array}{l}\text { vigésima } \\
\text { segunda }\end{array}$ & $\begin{array}{l}\text {... multiplicador Lagarange } \\
(31,83753) \ldots \text {. }\end{array}$ & $\begin{array}{l}\text {... multiplicador Lagarange } \\
(31,89170) \ldots\end{array}$ \\
\hline 48 & 4.2 & sétima & $\begin{array}{l}\text { efeito marginal: } 0,25907 \mathrm{e} \\
\text { estatística t: } 2,916\end{array}$ & $\begin{array}{l}\text { efeito marginal: } 0,25338 \quad \mathrm{e} \\
\text { estatística t:-2,835 }\end{array}$ \\
\hline 48 & 4.2 & décima sétima & $\begin{array}{l}\text { Média: } 0,1369 \text { e desvio } \\
\text { padrão: } 0,3447\end{array}$ & $\begin{array}{l}\text { Média: } 0,1688 \text { e desvio padrão: } \\
0,0972\end{array}$ \\
\hline 49 & 4.2 & vigésima & $\begin{array}{l}\ldots \text { apresentou valor de } \\
30,45 \ldots\end{array}$ & $\ldots$ apresentou valor de $30,38 \ldots$ \\
\hline 55 & 5 & Vigésima quarta & $\begin{array}{l}\text {... renda média familiar } \\
\text { per capita mensal... }\end{array}$ & ... renda média familiar mensal... \\
\hline
\end{tabular}




\section{Dados Internacionais de Catalogação na Publicação (CIP) DIVISĀO DE BIBLIOTECA E DOCUMENTAÇĀO - ESALQ/USP}

\section{Mendes, Carlos Magno}

Disposição de pagara por alimentos seguros : o caso dos hortifruticolas sem resíduos de agrotóxicos / Carlos Magno Mendes. - - Piracicaba, 2002.

$72 \mathrm{p}$.

Tese (doutorado) - Escola Superior de Agricultura Luiz de Queiroz, 2002.

Bibliografia.

1. Alimentos - Segurança 2. Comportamento do consumidor 3. Produto hortifruticola - Aspecto econômico 4. Resíduos de pesticidas em plantas 5. Toxicologia de alimentos I. Título

CDD 338.17

"Permitida a cópia total ou parcial deste documento, desde que citada a fonte - 0 autor"

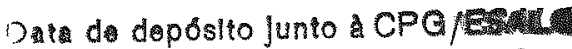

$04 / 10 / 2002$ 


\section{OFEREÇO}

Aos meus pais in memoriam:

Sr. Gute e Dona Tita.

DEDICO

A minha esposa Izabel, companheira de todas as horas. 


\section{AGRADECIMENTOS}

Ao concluir este estudo vem a percepção clara de quão importantes foram as contribuições recebidas ao longo da trajetória e desenvolvimento deste trabalho. Desta forma, gostaria de registrar aqui os meus agradecimentos:

- à Universidade Federal de Mato Grosso (UFMT) através do PICDT/ CAPES e aos colegas de Departamento de Economia pela liberação, especialmente aos Professores Dr. Benedito Dias Pereira, Prof. Dr. Manuel Marta e Leila Metello;

- aos Professores Dr. Paulo Fernando Cidade de Araújo e Dr ${ }^{\mathrm{a}}$ Zilda Paes de Barros Mattos meus orientadores. Ao Dr. Paulo pelo júbilo demonstrado na fase embrionária deste estudo e a $\mathrm{Dr}^{\mathrm{a}}$. Zilda pelas idéias, pela confiança, pela amizade e pela prestimosidade durante as demais fases deste trabalho;

- aos professores Dr. Alexandre Lahóz Mendonça de Barros, Dr. Evaristo Marzabal Neves, Dr. Ricardo Shirota e Dr. Adriano Julio B.V. de Azevedo Filho, pelas valiosas críticas e sugestões apresentadas em fases anteriores deste trabalho;

- aos funcionários e professores da Escola Superior de Agricultura "Luiz de Queiroz", do Departamento de Economia, Administração e Sociologia, pelas contribuições e ensinamentos;

- a Professora $\mathrm{Dr}^{\mathrm{a}}$ Ana Lúcia Kassouf pelos esclarecimentos de dúvidas na parte econométrica; 
- ao Médico Veterinário Ademir de Lucas e a equipe de colaboradores, alunos do Curso de graduação da Economia Agroindustrial e Engenharia Agronômica da ESALQ: Ana Paula, Andréia, Ana Helena, Elaine, Egmar, Flávia, Juliana, Ricardo, Reginaldo e Simone pela presteza e forma precisa com que realizaram as entrevistas;

- aos colegas de pós: Ari, Casimiro, Alexandre "Conhas", Carla, Cleise e Emerson, Estevão, Denise, Elaine, Jaênes e Cândida, Marcos, Marcelo Rezende, Márcia, Malagueta (entomologia), Nicolela, Patrícia e Silvano (estatística) pelos momentos desfrutados na ESALQ;

- aos moradores da cidade de Piracicaba que participara das entrevistas e que no anonimato ajudaram a consolidar este trabalho;

- à todos aqueles que diretamente ou indiretamente contribuíram para o êxito desse trabalho. 


\section{SUMÁRIO}

Página

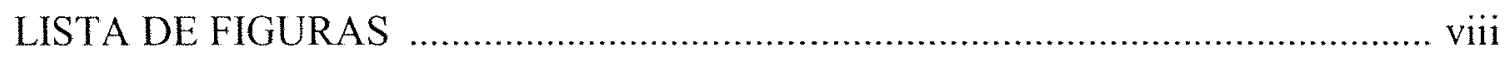

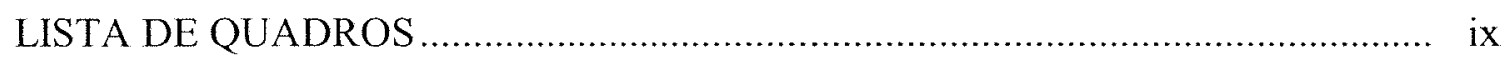

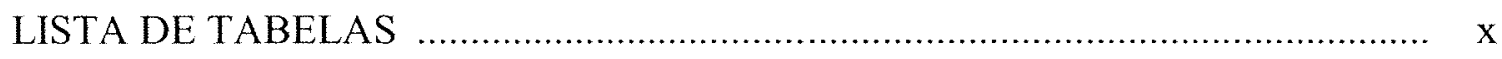

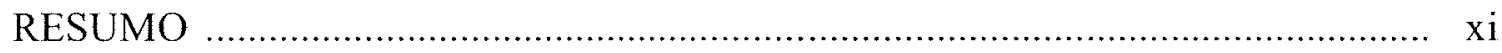

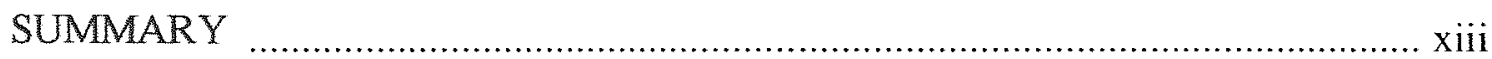

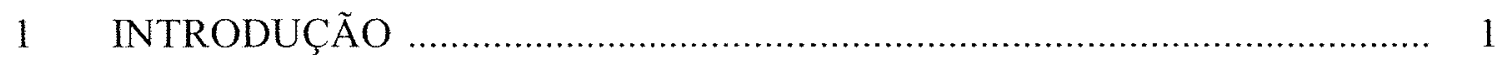

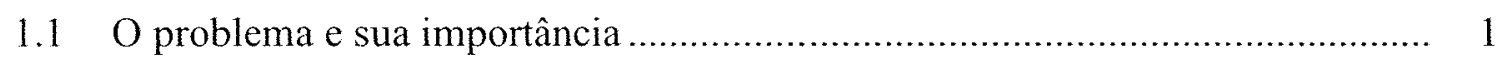

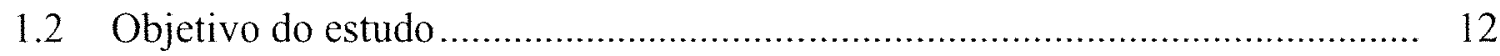

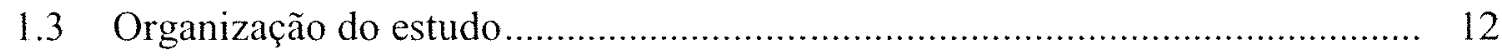

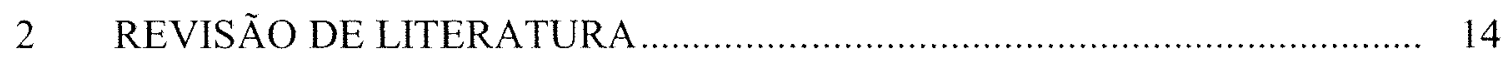

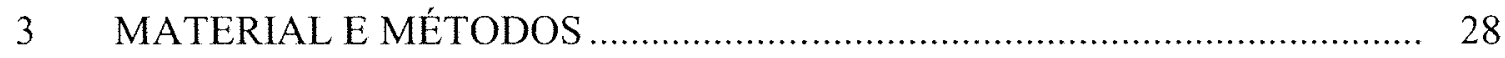

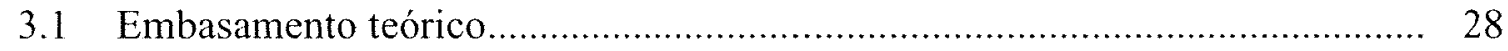

3.2 Especificação do modelo a ser estimado .............................................. 31

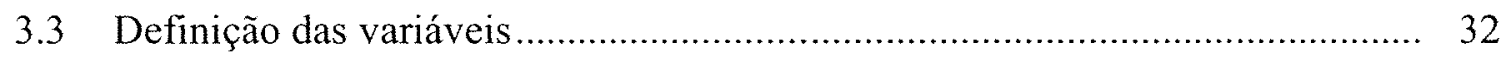

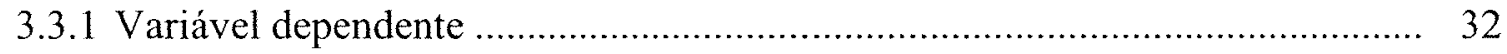

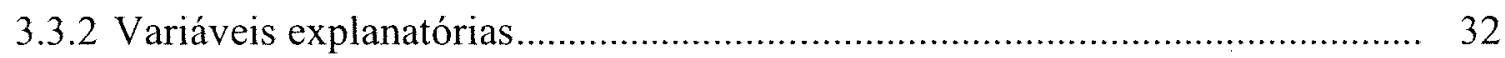

3.4 Caracterização da área de estudo .................................................... 36

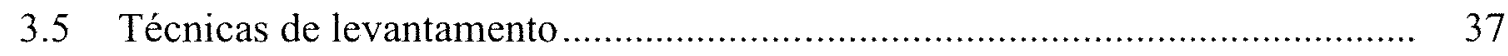

3.6 Caracterização da pesquisa de campo.................................................. 38

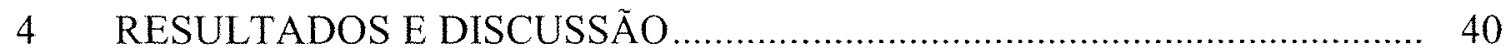

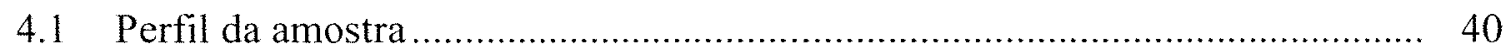

4.2 Estimativas do modelo econométrico ..................................................... 46 
5 CONCLUSÕES

ANEXOS 58

REFERÊNCIAS BIBLIOGRÁFICAS 


\section{LISTA DE FIGURAS}

Página

1 Resultados de análise de resíduos por produtos de 1994 a 1998 em São Paulo

2 Número de pesticidas detectado em Total Diet Study, 1965-1991 10

3 Distribuição de freqüência dos entrevistados por faixa etária. 41

4 Emissão de certificado de ausência de agrotóxicos 44 


\section{LISTA DE QUADROS}

Página

1 Pesticidas comumente encontrados nos E.U.A e seus efeitos sobre a saúde.

2 Casos registrados de intoxicação humana por agente tóxico e causa indeterminada, Brasil, 1998 .......................................................................... 06

3 Resultados de análises de resíduos por produto, São Paulo, 1994 a 1998 ............. 08

4 Justificativas apresentadas pelos entrevistados da amostra para não pagar mais por HSA 


\section{LISTA DE TABELAS}

Página

1 Modelo lógite de disposição a pagar de hortifrutícolas sem agrotóxicos

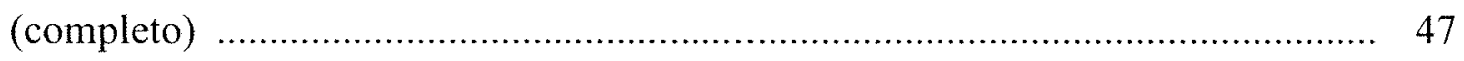

2 Estatísticas descritivas do modelo proposto ....................................................... 48

3 Modelo lógite de disposição a pagar por hortifrutícolas livre de

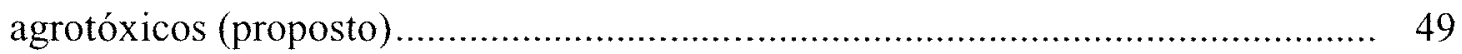




\title{
DISPOSIÇÃO A PAGAR POR ALIMENTOS SEGUROS: O CASO DOS HORTIFRUTÍCOLAS SEM RESÍDUOS DE AGROTÓXICOS
}

\author{
Autor: CARLOS MAGNO MENDES \\ Orientadora: Prof ${ }^{\mathrm{a}}{ }^{\mathrm{Dr}}{ }^{\mathrm{a}}$ ZILDA PAES DE BARROS MATTOS
}

\section{RESUMO}

O objetivo deste estudo foi investigar os possíveis determinantes da disposição de pagar (DDP) mais por produtos hortifrutícolas in natura sem agrotóxicos (HSA) de uma amostra aleatória de 314 consumidores, no município de Piracicaba, no Estado de São Paulo, usando para tal, um modelo lógite. A análise desenvolvida teve por base o método de valoração contingente dado o reduzido tamanho do mercado dos produtos sem agrotóxicos. As entrevistas foram realizadas nos locais de compra de hortifrutícolas distribuídos pela cidade, durante os meses de abril e maio de 2002. Apesar de aleatória, a amostra ficou caracterizada, na média, por indivíduos com alta renda e alto grau de instrução, o que não surpreende dada a localização da área de estudo. Mais de dois terços $(69 \%)$ da amostra era do sexo feminino, com idade média de 43 anos. Os resultados mostraram que $87 \%$ dos entrevistados sabiam que produtos hortifrutícolas podem estar contaminados com resíduos de agrotóxicos. Uma das principais fontes dessa informação, apontada pelos entrevistados, foi a mídia. Desta forma, esta última poderia exercer um papel essencial em programas orientados aos consumidores, alertando-os com relação ao consumo de alimentos seguros e estimulando sua comercialização atuando, dessa forma, na melhoria da saúde pública. Os resultados mostraram que, dentre 
as variáveis explicativas da DDP especificadas no modelo, o 'preço', 'grupo de risco', 'testado pelo governo' e 'atitude' constituíram fatores significativos na explicação da disposição de pagar mais por HSA. Assim, a importância do preço e a escolha do governo como órgão certificador diminuem a probabilidade de os consumidores pagarem mais por HSA. Por outro lado, a existência de pessoas consideradas mais vulneráveis tais como crianças, gestantes, idosos e pessoas com doença crônica ('grupo de risco') na família e a atitude dos entrevistados em prol de políticas mais restritivas com respeito aos agrotóxicos aumentam a probabilidade de os consumidores pagarem mais por HSA. Com relação a esta última, os resultados mostraram que para $92 \%$ dos consumidores, todos os agrotóxicos deveriam ser definitivamente proibidos (banidos) ou os que não são seguros deveriam ser proibidos e os restantes deveriam sofrer maiores restrições. $\mathrm{O}$ aumento da população mundial pressionando a demanda por alimentos faz surgir, no admirável mundo da engenharia genética como da pesquisa agropecuária tradicional, uma enorme necessidade de produção de alimentos. Contudo, é necessário que todo esse avanço tecnológico esteja associado a uma produção que garanta o bem-estar das pessoas, começando pela segurança dos alimentos produzidos, seja através de uma agricultura sustentável ou processados em laboratórios. A prosperidade de um país também é garantida quando ele é capaz de produzir os alimentos necessários para nutrir seus habitantes, mas sem que isso implique em sérios, e principalmente desconhecidos, riscos de saúde pública. 


\title{
WILLINGNESS TO FOR SAFE-FOOD: THE CASE OF PESTICIDE RESIDUE-FREE FRESH PRODUCE
}

\author{
Author: CARLOS MAGNO MENDES \\ Adviser: PROF ${ }^{\mathrm{a}}$ DR $^{\mathrm{a} .}$ ZILDA PAES DE BARROS MATTOS
}

\section{SUMMARY}

The objective of this study was to investigate the possible determinants of the willingness-to-pay (WTP) a higher price for certified pesticide residue-free fresh produce (RFFP) from a random sample of 314 consumers, in the municipio of Piracicaba, in the state of São Paulo, using a logit model. The analysis had the contingent valuation method (CVM) as its basis given the small size of the market for pesticide residue-free products. The interviews were undertaken in specialized stores (supermarkets included) located throughout the city, during the month of April and May, 2002. Although being random, the sample was characterized, on average, by persons with high income and high level of education, which was not surprising given the localization of the study area. More than two thirds $(69 \%)$ of the sample was female and, 43 years old, on average. The results showed that $87 \%$ of the shoppers knew that pesticide residues might contaminate fresh produce. One of the most important sources of that information, pointed by the respondents, was the media. Thus, the media could have an essential role in programs oriented to consumers, alerting them with respect to the consumption of safe foods and stimulating their commercialization, acting therefore to improve public health. The results showed that among the explanatory variables specified in the model, 
'price', 'risk group', 'tested by the government' and 'attitude' were significant factors in the explanation of consumers' willingness to pay higher prices for RFFP. Thus, the importance of price and the choice of government as RFFP's certificator reduce consumers' probability to pay higher prices for pesticide residue-free produce. On the other hand, the existence of more vulnerable persons in the family such as children, pregnant women, old people as well as persons with chronic disease ('risk group') and consumers' attitude favoring more restrictive policies for pesticides increase consumers' probability to pay more for RFFP. With respect to the latter, the results showed that for $92 \%$ of the consumers, all pesticides should be banned or those, which are not safe, should be banned with greater restrictions on remaining pesticides. The increase in world population, pressuring food demand, creates, in the admirable genetic engineering as well as in the traditional agricultural research world, an enormous need for food production. However, it is necessary that all the technological advance be associated with a production that guarantees the well being of the people, starting by the safety of the food produced, be it through traditional agriculture or laboratory processed. Nation's prosperity is also guaranteed when she is capable of producing enough food to feed her people but without imposing serious, and mainly unknown, risks to public health. 


\section{INTRODUÇÃO}

\subsection{O problema e sua importância}

Os efeitos dos agrotóxicos ${ }^{1}$ sobre a saúde do homem têm sido alvo de estudos desde a Primavera Silenciosa de Rachel Carson, escrito em 1962. Sabe-se, hoje, que muitos desses produtos podem causar perturbações nos sistemas endócrino e imunológico, fibrose pulmonar e câncer, dentre outros efeitos. A ação pode-se dar via ar, água ou alimentos contaminados. Este estudo está centrado nos alimentos contaminados, mais precisamente no processo de tomada de decisão de consumo de hortifrutícolas sem agrotóxicos (HSA) in natura, na cidade de Piracicaba. Seu objetivo principal é avaliar as influências de diversos fatores sobre a probabilidade de o consumidor pagar mais por HSA. De certa forma, procura-se averiguar como os consumidores reagem frente ao uso dos agrotóxicos e a presença de resíduos nos produtos perecíveis, utilizando uma amostra de consumidores da cidade de Piracicaba, no Estado de São Paulo. Espera-se, com os resultados obtidos neste estudo, poder subsidiar a formulação de políticas de saúde pública.

A agricultura moderna tem exercido papel fundamental no fornecimento de matéria-prima para a alimentação humana e animal. Segundo a FAO - Food and Agriculture Organization of the United Nations, a população que, há cerca de 200 anos, se duplicava em 123 anos, agora o faz em apenas 12. Isso significa que o prazo

\footnotetext{
"Seguindo o mesmo critério da Portaria $n^{0}$ 295/1971, o neologismo "agrotóxico" é adotado neste trabalho para definir os insumos químicos utilizados no combate às pragas, doenças e ervas invasoras das lavouras, por exprimir com maior adequação e realismo a sua periculosidade aos seres vivos e ao ambiente. Também podem ser denominados de pesticidas, biocidas e defensivos (Pessanha \& Menezes, 1985).
} 
disponível para o provimento de alimento, empregos e moradias é, no presente, dez vezes menor que do que há dois séculos. Constata-se que, graças à tecnologia mecânicoquímica atual, a área necessária para nutrir uma pessoa diminuiu em quase $50 \%$ de 1950 para cá e a área agrícola triplicou desde 1950 (Primavesi, 2000). Uma das características dessa tecnologia mecânico-química que permitiu chegar a essas cifras foi o elevado uso de agrotóxicos para combater insetos, fungos e plantas daninhas em várias culturas. Esses produtos são vistos como uma solução rápida e eficiente para regular as perdas causadas pelas pragas e doenças nas plantações. Seu emprego foi promovido por governos nacionais na suposta condição de propiciar a auto-suficiência alimentar e aumentar a renda no campo. Para Cerri $(2001$, p. 48), "toda a ênfase da pesquisa desde o pós-guerra foi para desvincular a agricultura dos seus condicionantes naturais e subordiná-la aos imperativos do crescimento industrial".

No Brasil, o uso de agrotóxicos, à semelhança dos Estados Unidos, fez parte integrante do modelo de modernização da agricultura adotado no final dos anos 60 . Em 1975, seu uso recebeu estímulo especial por meio do Programa Nacional de Defensivos Agrícolas (PNDA), o qual destinou US\$ 200 milhões para a implantação e desenvolvimento das indústrias de agrotóxicos (Pessanha \& Menezes, 1985). A argumentação de alguns setores, principalmente dos fabricantes, é que, sem a incorporação dessa alta tecnologia, seria difícil atender à elevada demanda por alimentos de uma crescente população que passa a ser predominantemente urbana, sem aumentar as pressões sobre o habitat natural das espécies animais e vegetais.

Não há dúvida de que o mundo vem assistindo a avanços tecnológicos, no setor agrícola, desde meados do século passado. Entretanto, essas novas técnicas trouxeram surpresas nada agradáveis. Segundo Zadocks \& Waibel (2000), a primeira lição da "história dos defensivos" é que, apesar da estrutura reguladora sofisticada, efeitos externos negativos provenientes da produção agropecuária continuam a existir, isto é, custos que não são suportados pelos usuários de defensivos mas que a sociedade tem de pagar. Tornou-se óbvio que há dois tipos de efeitos externos. De acordo com 
Waibel et $\mathrm{al}^{2}$. (1999, citado por Zadocks \& Waibel 2000), primeiro aparecem os efeitos externos off-site, como a poluição das águas pelos agrotóxicos, impondo, por exemplo, um custo de, no mínimo, 130 milhões de marcos, por ano, à sociedade, na Alemanha. Em seguida, surgem os efeitos externos de natureza intertemporal ou mesmo intergeração. O Quadro 1 mostra alguns dos sérios danos à saúde humana causados pelos agrotóxicos.

\begin{tabular}{|l|l|l|}
\hline \multicolumn{1}{|c|}{ Grupo químico } & \multicolumn{1}{|c|}{ Exemplo } & \multicolumn{1}{|c|}{ Efeito tóxico } \\
\hline Inseticidas & DDT, lindane, dieldrin, clordane & $\begin{array}{l}\text { Carcinogênicos } \\
\text { Perturbação } \\
\text { endócrina } \\
\text { Neurotóxicos }\end{array}$ \\
\hline Organofosforados & Parathion, clorpirifós & Neurotóxicos \\
\hline Carbamatos & Aldicarb & Neurotóxicos \\
\hline Piretróides & Ciflutrin, permethrin fenvalerate & $\begin{array}{l}\text { Possíveis causadores } \\
\text { de perturbação } \\
\text { endócrina }\end{array}$ \\
\hline Herbicidas & $\begin{array}{l}\text { Paraquat, diquat } \\
\text { Atrazina, alaclor }\end{array}$ & $\begin{array}{l}\text { Fibrose pulmonar } \\
\text { Carcinogênico }\end{array}$ \\
\hline
\end{tabular}

Quadro 1 - Pesticidas comumente encontrados nos E.U.A e seus efeitos sobre a saúde. Fonte: Landrigan (2001)

${ }^{2}$ WAIBEL, H.; FIEICHER, G.; BECKER, H. The economic benefits of pesticides: a case study form Germany. Agrarwirtschaft, v.48, p.219-230, 1999. 
De acordo com Pimentel et al. (1993), as doenças e intoxicações humanas são, claramente, o mais alto preço pago pelo seu uso. Os prejuízos para saúde mais conhecidos são os agudos, por serem mais evidentes e imediatos. Segundo a Pan Americam Health Oragnization ${ }^{3}$ (1993, citada por Garcia 1996), a população da América Latina expõe-se a quantidades significativas de praguicidas por meio de resíduos em alimentos.

Segundo Landrigan (2001, p.13), “ao contrário das primeiras gerações de pesticidas, como o DDT, esses compostos [organofosforados, carbamatos e piretróides] têm vida curta no meio ambiente e não se acumulam no corpo humano. Entretanto, os organofosforados e os carbamatos são tóxicos para o sistema nervoso, e evidência recente sugere que certos piretróides podem ser tóxicos para o sistema reprodutor e causar disfunção endócrina". Le Couteur et al. (1999) concluem, em seu trabalho de revisão, que "embora alguns estudos tenham sido conflitantes, há evidência razoável de associação entre Doença de Parkinson e exposição a pesticidas. Uma série de metaanálises de estudos publicados com pareceristas encontraram uma pequena mas significativa elevação do risco de Doença de Parkinson em indivíduos que vivem em zona rural, utilizam água de poço, são expostos a animais ou atividades rurais e a pesticidas (Priyardashi et al., 2001).

Diversos autores (Landrigan, 2001; Le Couteur et al., 1999; Wiles et al., 1998, entre outros) chamam a atenção para um fato altamente preocupante: a maior exposição aos inseticidas a que estão sujeitas as crianças, quando comparadas aos adultos. De acordo com a National Research Council 4 (1993, citado por Landrigan, 2001), o fato de as crianças, $\mathrm{kg}$ por $\mathrm{kg}$ de peso, comerem mais, beberem mais água e

\footnotetext{
${ }^{3}$ PAN AMERICAN HEALTH ORGANIZATION. Pesticides and health in the Americas. Washington, 1993. 109p. (Environmental Series, 12)

${ }^{4}$ NATIONAL RESEARCH COUNCIL. Pesticides in the diets of infants and children. Washington, National Academy Press, 1993.
} 
respirarem mais do que os adultos, as tornam mais expostas aos agrotóxicos. Há risco de danos de longo prazo no cérebro e no sistema nervoso de indivíduos expostos a inseticidas organofosforados durante seus primeiros anos de vida (Wiles et al., 1998). Esses autores estimam que, nos EUA, mais de um milhão de crianças com até 5 anos de idade (1 em cada 20) comem diariamente doses não seguras de inseticidas organofosforados e que 100.000 dessas crianças excedem a dose segura (10 vezes ou mais) estabelecida pela Agência de Proteção Ambiental (Environmental Protection Agency).

Os efeitos do uso de agrotóxicos, nos países em desenvolvimento, também são bastante preocupantes. Estima-se que cerca de $2 \%$ da população brasileira é contaminada anualmente por praguicidas e para cada caso constatado, em hospitais e ambulatórios, deve haver, aproximadamente, 250 vítimas não-registradas, principalmente pela falta de conhecimentos toxicológicos dos médicos (Araújo et al., 2000). Um levantamento do Sistema Nacional de Informações Tóxico-Farmacológicas (Sintox), órgão do Ministério da Saúde vinculado à Fundação Oswaldo Cruz (Fiocruz), revelou um quadro preocupante: aumenta, a cada ano, o número de mortes causadas por agrotóxicos no país. Os óbitos notificados subiram $26 \%$, isto é, de 143, em 1997, para 181, em 1998. Este trabalho recolheu dados de 32 centros de assistência toxicológica em 17 estados brasileiros (Levy, 1999). O número de mortes por agrotóxicos, no Brasil, perde para o número de mortes por medicamentos $(28 \%)$, animais peçonhentos $(24 \%)$, produtos de limpeza doméstica $(7,5 \%)$ e produtos químicos industriais $(6,7 \%)$, mas está à frente de outros produtos tóxicos, como raticidas $(3,7 \%)$ e plantas tóxicas $(2,2 \%)$ (Quadro 2). 


\begin{tabular}{|c|c|c|c|c|c|c|c|c|}
\hline \multirow[t]{2}{*}{ Agente } & \multicolumn{6}{|c|}{ Causa } & \multicolumn{2}{|c|}{ Total } \\
\hline & Acidente & Abuso & Suicídio & $\begin{array}{l}\text { Profis- } \\
\text { sional }\end{array}$ & Outros & $\begin{array}{l}\text { Indeter- } \\
\text { minada }\end{array}$ & $\mathbf{N}^{\mathbf{0}}$ & $\%$ \\
\hline Medicamentos & 9761 & 365 & 8997 & 98 & 2368 & 792 & 22381 & 28,20 \\
\hline Animais peçonhentos & 16025 & 0 & 0 & 2696 & 264 & 448 & 19433 & 24,49 \\
\hline $\begin{array}{l}\text { Animais não } \\
\text { peçonhentos }\end{array}$ & 4429 & 0 & 0 & 196 & 24 & 52 & 4701 & 5,92 \\
\hline $\begin{array}{l}\text { Produtos químicos } \\
\text { industriais }\end{array}$ & 3614 & 289 & 467 & 749 & 117 & 120 & 5356 & 6,75 \\
\hline $\begin{array}{l}\text { Pesticidas } \\
\text { Agropecuários }\end{array}$ & 1607 & 8 & 1824 & 1663 & 66 & 100 & 5268 & 6,64 \\
\hline $\begin{array}{l}\text { Pesticidas } \\
\text { Domésticos }\end{array}$ & 1447 & 7 & 839 & 138 & 73 & 87 & 2591 & 3,26 \\
\hline Raticidas & 1273 & 5 & 1521 & 30 & 67 & 85 & 2981 & 3,76 \\
\hline Domissanitários & 4749 & 15 & 751 & 246 & 83 & 116 & 5960 & 7,51 \\
\hline Produtos de toalete & 664 & 3 & 37 & 9 & 30 & 20 & 763 & 0,96 \\
\hline Plantas & 1416 & 101 & 67 & 16 & 113 & 35 & 1748 & 2,20 \\
\hline $\begin{array}{l}\text { Intoxicação por } \\
\text { alimentos }\end{array}$ & 391 & 6 & 0 & 4 & 340 & 7 & 748 & 0,94 \\
\hline Outros produtos & 1344 & 2686 & 335 & 743 & 173 & 238 & 5519 & 6,95 \\
\hline Não determinados & 655 & 26 & 134 & 40 & 130 & 932 & 1917 & 2,42 \\
\hline Total & 47375 & 3511 & 14972 & 6628 & 3848 & 3032 & 79366 & 100,00 \\
\hline
\end{tabular}

Quadro 2 - Casos registrados de intoxicação humana por agente tóxico e causa indeterminada, Brasil, 1998.

Fonte: Levy (1999) 
Nos alimentos, os resíduos de agrotóxicos podem ser resultados de aplicação direta em uma das fases da produção, do transporte ou do armazenamento. Desse modo, alimentos contaminados associados aos resíduos, nos reservatórios de água e no solo, tornam-se importantes fontes de exposição aos agrotóxicos para a população em geral, principalmente vegetais e frutas, que recebem maiores dosagens, especialmente quando consumidos in natura. No que se refere ao solo, uma pesquisa desenvolvida pela Embrapa (Empresa Brasileira de Pesquisa Agropecuária) diagnosticou que o megarreservatório de água doce (aqüífero Guarani), capaz de abastecer o país por 2500 anos, vem sendo contaminado por agrotóxicos nas áreas próximas à superfície (Lopes, 2002).

Neves et al. (2002) ao determinarem estimativas de demanda relativa ( $\mathrm{kg}$ de ingrediente ativo/hectare) por defensivos agrícolas pelas principais culturas em 2000, verificaram que a maçã, o tomate, a batata, os citrus e as uvas ocuparam os primeiros lugares no consumo por ingrediente ativo no Brasil. $\mathrm{Na}$ classe de fungicidas, o posicionamento das 5 principais culturas foi: tomate, maçã, batata, uva e citrus, e, para inseticidas, obteve-se: tomate, algodão, batata, maçã e citrus.

Segundo Leite (1999), os produtos mais fortemente associados à boa saúde, como citros, maçã e tomate (hortifrutícolas de um modo geral), têm recebido pouca atenção em relação ao seu sistema de monitoramento, deixando o consumidor brasileiro completamente sem defesa (Quadro 3). Este tem sido o dado que mais preocupa o IBGE por não conseguir aferir, no país, em que escala o produto que chega à mesa do consumidor está contaminado pelo uso errado dos pesticidas e fertilizantes (Comércio de agrotóxico..., 2002). A presença de princípios ativos não permitidos ou não autorizados por lei foram encontrados em várias análises de produtos hortifrutícolas, na cidade de São Paulo (Quadro 3). 


\begin{tabular}{|c|c|c|c|c|c|}
\hline Produto & Amostra & Sem resíduo & Abaixo $\mathbf{L M R}^{1}$ & Acima $\mathrm{LMR}^{1}$ & $\mathrm{NPC}^{2}$ \\
\hline \multicolumn{6}{|l|}{ Legume } \\
\hline Cenoura & 63 & 62 & 1 & - & - \\
\hline Pepino & 5 & 3 & - & - & 2 \\
\hline Pimenta & 2 & 2 & - & - & - \\
\hline Pimentão & 37 & 22 & 3 & 7 & 5 \\
\hline Tomate & 203 & 111 & 68 & 6 & 18 \\
\hline Vagem & 40 & 26 & - & - & 14 \\
\hline \multicolumn{6}{|l|}{ Fruta } \\
\hline Caqui & 61 & 60 & - & - & 1 \\
\hline Goiaba & 77 & 50 & 12 & - & 15 \\
\hline Laranja & 43 & 40 & - & - & 3 \\
\hline Limão & 5 & 5 & - & - & - \\
\hline Maçã & 61 & 54 & 5 & - & 2 \\
\hline Mamão & 141 & 126 & 1 & - & 14 \\
\hline Morango & 291 & 95 & 100 & 5 & 91 \\
\hline Pêssego & 120 & 73 & 21 & 2 & 24 \\
\hline Poncã & 40 & 40 & & - & - \\
\hline Uva & 113 & 96 & 6 & - & 11 \\
\hline
\end{tabular}

Quadro 3 - Resultados de análises de resíduos de agrotóxicos, por produto, São Paulo, 1994 a $1998\left(\mathrm{em} \mathrm{n}^{\circ}\right)$.

Fonte: Adaptado a partir de Gorenstein (2000)

${ }^{1} \mathrm{LMR}$ - Limite Máximo de Resíduo

${ }^{2} \mathrm{NPC}$ - Não Permitido para a Cultura

Segundo Caldas e Souza (2000), o Brasil não possui, atualmente, um programa nacional de monitoramento de resíduos de pesticidas em alimentos, e são escassos os dados de resíduos em alimentos prontos para serem consumidos. Ainda, para estes autores, os limites máximos de resíduos (LMR) estabelecidos pela legislação brasileira são os únicos parâmetros disponíveis para todos os pesticidas em todas as culturas. Como pode ser observado no Quadro 3, os exames feitos em amostras coletadas 
culturas. Como pode ser observado no Quadro 3, os exames feitos em amostras coletadas para os diversos produtos hortifrutícolas indicam resíduos de substâncias químicas não permitidas para essas culturas. A Figura 1 apresenta as que mais se destacam nessa análise: morango $(31,27 \%)$, pêssego $(20 \%)$ e tomate $(8,87 \%)$.

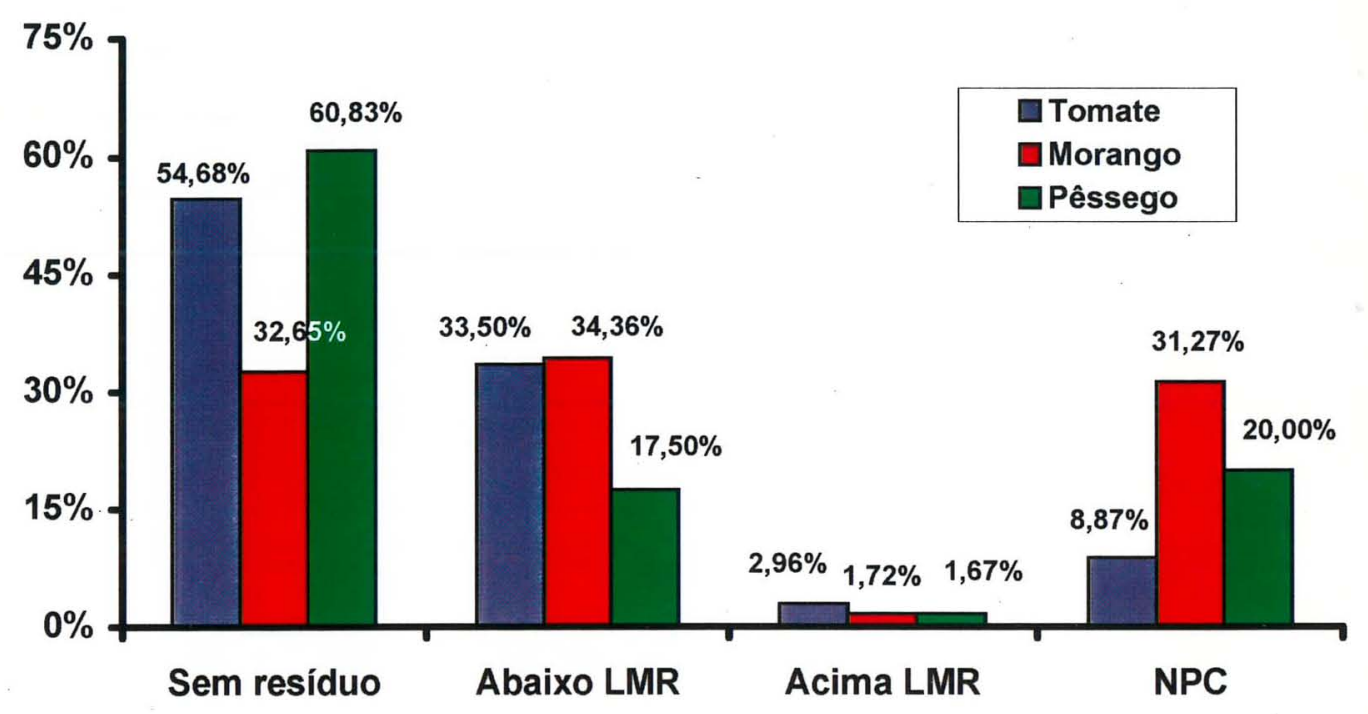

Figura 1 - Resultados de análise de resíduos de agrotóxicos, por produto, de 1994 a 1998, São Paulo.

Fonte: Elaborado pelo autor a partir do Quadro 3

LMR - Limite Máximo de Resíduo

NPC - Não Permitido para a Cultura

Não basta lavar ou descascar as frutas contaminadas; esta é, apenas, uma medida paliativa pois os pesticidas sistêmicos são absorvidos e distribuídos pela seiva das plantas, impregnando o interior dos frutos de forma definitiva (Leite 1999). Entre 1979 e 1987, em vários tipos de alimentos processados, como sardinha em óleo, atum em azeite e salsicha, foram constatadas contaminações por organoclorados que, segundo Landrigan (2001), causam câncer, disfunção endócrina e são neurotóxicos. A pesquisadora Cláudia Helena Ciscato, do Instituto Biológico de São Paulo, revelou ter 
proibidos desde 1985. Foram avaliadas amostras, aleatoriamente, entre 1996 e 1998. Em $13,2 \%$ do leite coletado nos caminhões e em $8,1 \%$ do leite comprado no mercado havia resíduos (Uso incorreto ..., 2002).

Segundo Day et al. (1995), o número de pesticidas detectado no mercado norte-americano tem aumentado, substancialmente, a cada ano, nas últimas décadas (Figura 2). Entretanto, como apontam esses autores, não fica claro se o aumento nas contaminações, naquele país, deve-se à melhoria nos processos de detecção de resíduos químicos ou ao aumento do número de agrotóxicos disponíveis no mercado.

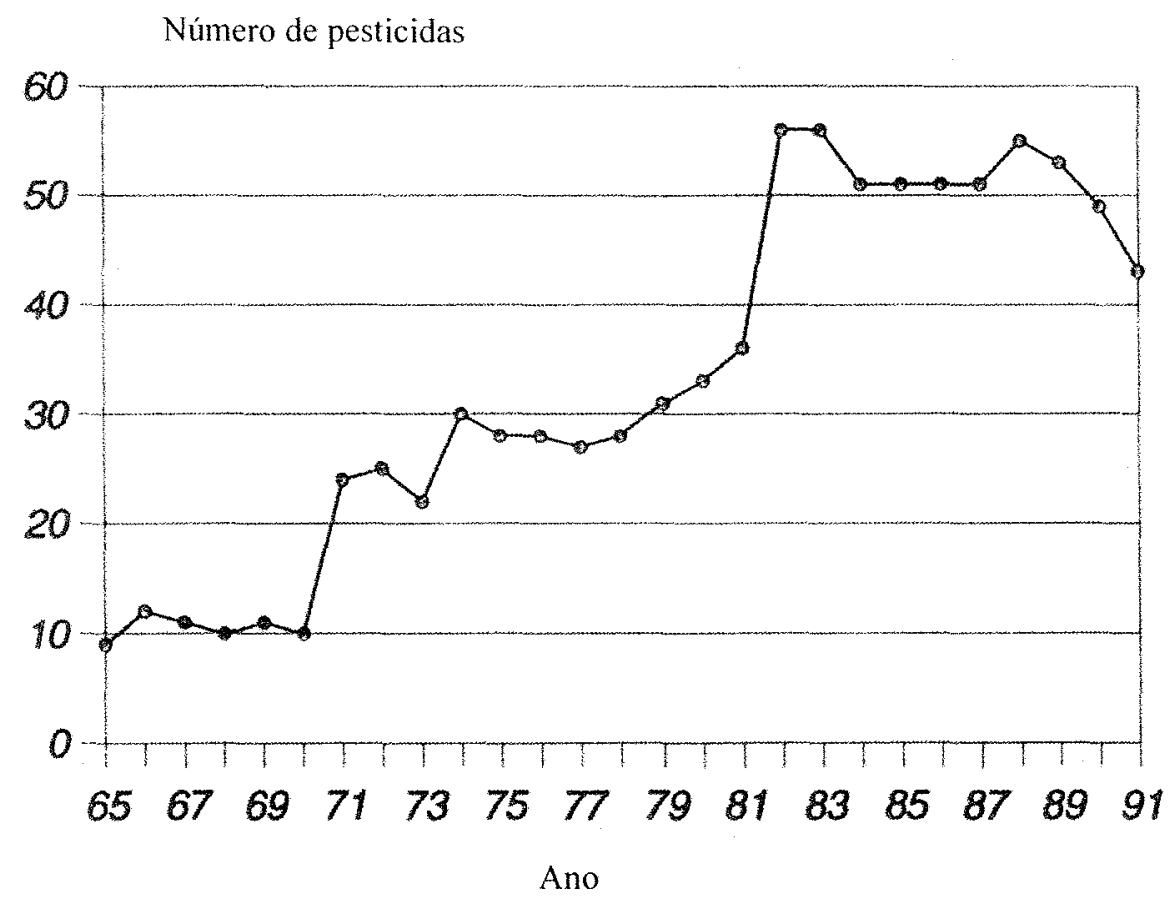

Figura 2 - Número de pesticidas detectado em Total Diet Study, 1965-1991. Fonte: Day et al (1995) 
Por outro lado, é oportuno ressaltar que o consumidor se depara com outras sérias dificuldades, principalmente no que diz respeito à informação sobre os produtos alimentares à venda, particularmente aqueles cultivados sem agrotóxicos, cujos atributos são difíceis de serem observados na hora da compra, uma vez que estão associados à forma de condução do processo produtivo. A impossibilidade de distinção entre a presença ou ausência de altas doses de resíduos químicos ou substâncias tóxicas nesses alimentos, pelos consumidores, contribuem para a existência de assimetria de informação nesses mercados. A assimetria de informação existe quando o vendedor sabe muito mais a respeito da qualidade e segurança do produto do que qualquer comprador (Akerlof, 1970).

Alguns casos ocorridos nos EUA e na Europa com alguns alimentos devem, provavelmente, ter servido para alertar os consumidores daqueles países a respeito da assimetria de mercado definida por Akerlof. Nos EUA, dentre outros, os consumidores foram alertados pela mídia para os problemas causados pelo químico ALAR usado na produção de maçã e pelo suco de maçã da indústria Odwalla, contaminado pela bacteria e.coli. Na Europa, pode-se citar o caso da contaminação dos frangos por dioxina, na Bélgica; a "doença da vaca louca", em diversos países europeus, e as declarações do cientista Dr. Árpád Pusztai ${ }^{5}$, na Escócia, sobre os efeitos maléficos da batata transgênica no sistema imunológico de cobaias. Assim, pode-se entender a forte reação contrária dos consumidores europeus aos produtos transgênicos como sendo, em parte, resultado de uma maior conscientização acerca dessa assimetria de mercado.

O crescimento da produção de alimentos sem resíduos de agrotóxicos químicos (principalmente alimentos orgânicos), na Europa, de 250 mil hectares, em 1987, para 2,9 milhões de hectares em 2000 (Cerri, 2001), também evidencia uma crescente exigência dos consumidores desses países quanto à segurança dos alimentos.

\footnotetext{
${ }^{5}$ http://www.psrast.org/pusztai.htm
} 
A identificação dos fatores que levam consumidores a essas mudanças de comportamento com relação à segurança dos alimentos tem sido objeto de inúmeros estudos nos paises desenvolvidos. Acredita-se que tal conhecimento possa contribuir para aumentar a eficácia das políticas de saúde pública. Por outro lado, os estudos realizados nos países em desenvolvimento são escassos e, no Brasil, em particular, são, na sua maioria, de natureza descritiva.

O fato de a sociedade brasileira começar a ter interesse e demonstrar uma maior preocupação pelos problemas de contaminação dos alimentos faz aumentar, ainda mais, a importância deste estudo.

\subsection{Objetivos do estudo}

O objetivo central deste estudo é analisar, por meio de entrevistas pessoais, na cidade de Piracicaba, no Estado de São Paulo, o comportamento dos consumidores com relação à segurança dos produtos hortifrutícolas in natura no que se refere à presença de resíduos de agrotóxicos nos mesmos. Especificamente, pretende-se:

a) analisar, descritivamente, a amostra do estudo, enfatizando as características dos consumidores em relação à segurança dos produtos hortifrutícolas.

b) analisar de que maneira fatores socioeconômicos e demográficos, a percepção do problema, a confiança no governo e o grau de exposição a agrotóxicos afetam a disposição dos consumidores para pagar por HSA in natura preços mais altos relativamente aos hortifrutícolas convencionais.

\subsection{Organização do estudo}

O estudo está organizado em cinco capítulos, incluindo a introdução. A proposta deste trabalho, no contexto da literatura nacional e internacional, encontra-se no 
capítulo 2 sob o título de revisão de literatura. O capítulo 3 apresenta a metodologia utilizada, que compreendeu o referencial teórico em que se baseou o estudo, o modelo econométrico adotado, a área de estudo e a técnica de levantamento de dados selecionada. Os resultados do levantamento de campo assim como a análise descritiva e a discussão do modelo econométrico são apresentados no capítulo 4. Finalmente, o capítulo 5 encerra o estudo com o resumo, as conclusões e recomendações para futuras pesquisas. 


\section{REVISÃO DE LITERATURA}

Nas últimas décadas, a atitude do consumidor frente ao uso de pesticidas e presença de seus resíduos nos produtos alimentares mudou, intensificando sua exigência de qualidade e segurança destes. A esse despertar do interesse do consumidor por alimentos mais saudáveis foi dado o nome de "segurança do alimento" (do inglês food safety $)^{6}$. Segundo Hobbs \& Kerr $\left(1992^{7}\right.$, citados por Spers, 1998), pode-se definir segurança do alimento como:

$$
\begin{aligned}
& \text { "a aquisição pelo consumidor, de alimentos de boa } \\
& \text { qualidade, livres de contaminadores da natureza, } \\
& \text { quimicos (pesticidas), biológicos (organismos } \\
& \text { patogênicos), fisicos (vidros, pedras), e ou de qualquer } \\
& \text { outra substância que possa acarretar problemas à } \\
& \text { saúde"(p.13). }
\end{aligned}
$$

Por essa definição e pelos objetivos já explicitados no capítulo 1, pode-se depreender que este estudo trata, apenas, de um segmento da área de "segurança do

\footnotetext{
${ }^{6}$ Este termo não deve ser confundido com "segurança alimentar", do inglês food security, que envolve aspectos relacionados ao abastecimento, por meio de uma oferta adequada de alimentos, de uma dada população via produção doméstica ou importações.

${ }^{7}$ HOBBS, J.E.; KERR, W. A cost of monitoring food safety and vertical coordination in agribusiness: whar can be learned from the British Food Safety Act 1990? Agribusiness an International Journal, v.8, n.6, p.575-584, 1992.
} 
alimento", particularmente aquele que diz respeito à presença de resíduos de agrotóxicos nos produtos hortifrutícolas in natura. O despertar do consumidor para essa dimensão da segurança do alimento, entretanto, parece não ter ocorrido logo nos primeiros anos após a publicação do livro Primavera Silenciosa, de Carson, mesmo nos E.U.A. Segundo Sachs, Blair \& Richter (1987), que estudaram o comportamento de consumidores do Estado da Pensilvânia, em 1965, a preocupação maior estava voltada para os efeitos adversos dos agrotóxicos sobre o meio ambiente, conforme resultados de Bealer \& Willits $^{8}$ (1968, citados pelos autores). Quase 20 anos mais tarde, Sachs, Blair \& Richter (1987) conduziram novo estudo na mesma região, mostrando que a preocupação dos consumidores com o meio ambiente já se igualava à preocupação com a saúde dos agricultores que aplicavam agrotóxicos e dos indivíduos que ingeriam alimentos produzidos com agrotóxicos. Os autores atribuíram esse fato à possibilidade de os consumidores considerarem que os problemas ambientais estavam sendo conduzidos a contento.

Por outro lado, a crescente preocupação dos consumidores com os riscos à saúde provenientes do uso de agrotóxicos foi, em parte, atribuída ao que os autores chamaram de 'tecnofobia' crescente que coexiste com a confiança do público de que a tecnologia irá, em última instância, resolver os problemas da sociedade"(p.99). Sachs, Blair \& Richter concluíram que os fatores socioeconômicos explicaram pouco da variação nas preocupações dos consumidores com agrotóxicos, tanto em 1965 como 1984. De lá para cá, cresceu muito o número de trabalhos publicados na área, principalmente no que se diz respeito à investigação dos fatores que compõem o processo decisório de compra por parte dos consumidores.

\footnotetext{
${ }^{8}$ BEALER, R.C.; WILLITS, F.K. Worriers and non-worriers among consumers about farmers' use of
} pesticides. Journal of Consumer Affairs, v.2, p.189-204, 1968. 
Durante algum tempo, predominaram, na literatura, estudos que se preocuparam primordialmente em investigar as características socioeconômicas e demográficas dos consumidores como os fatores determinantes da percepção dos mesmos quanto ao risco que alimentos com resíduos de agrotóxicos podem representar à saúde humana. Os trabalhos de Ott (1990), Weaver et al. (1992) e de Underhill \& Figueroa (1996) destacam-se dentro desse grupo.

Ott (1990) avaliou as relações entre quatro variáveis dependentes (preocupação com pesticidas, disposição para pagar preços mais altos por produtos sem resíduos de pesticidas, disposição para aceitar defeitos cosméticos nos produtos e disposição para aceitar danos causados por insetos nos produtos). Foram consideradas as seguintes variáveis independentes: experiência do consumidor com pesticidas e características socioeconômicas e demográficas dos consumidores. Os resultados mostraram que metade dos consumidores se mostrou preocupada com resíduos de agrotóxicos. Dois terços dos consumidores mostraram-se dispostos a pagar mais pelos hortifrutícolas certificados sem resíduos de agrotóxicos. A disposição a pagar mais por hortifrutícolas sem resíduos de agrotóxicos foi maior entre os consumidores de cor branca que cultivavam hortas domésticas. Os consumidores com renda de até US\$ 25.000,00 anuais e com educação superior mostraram-se mais dispostos a aceitar danos tanto cosméticos como aqueles causados por insetos.

Weaver et al. (1992) investigaram o comportamento de consumidores com relação ao uso de agrotóxicos nos produtos hortifrutícolas em geral e, no tomate, em particular. A amostra foi composta praticamente só de consumidores de cor branca (96\%), com alta renda, do sexo feminino (64\%) e quase a metade (48\%) com a idade entre 48 e 55 anos. Os resultados mostraram que a grande maioria estava preocupada com o uso de agrotóxicos tanto do ponto de vista pessoal como de meio ambiente (91\% dos entrevistados declararam-se preocupados com a contaminação dos lençóis freáticos). De toda a amostra, somente 19\% declararam-se não dispostos a pagar prêmio por tomates sem resíduos de pesticidas químicos (SRPQ), tendo sido considerada substancial, pelos autores, a disposição para pagar (DAP) pelos mesmos. Além da 
ausência de resíduos de agrotóxicos, o estudo mostrou ser o sabor um atributo também importante na decisão de consumir tomates, ao passo que o tamanho e a aparência dos tomates não foram valorizados. A preocupação com os efeitos dos agrotóxicos, entretanto, não fez com que a maioria dos consumidores (57\%) mudasse seus hábitos alimentares. Dentre aqueles que o fizeram, $41 \%$ passaram a comprar mais orgânicos ou produtos SRPQ, 22\% reduziram suas compras de hortifruti frescos e $28 \%$ pararam de comprar por medo.

Underhill \& Figueroa (1996) investigaram o potencial de comercialização de frutas e vegetais in natura, com rótulos indicando seus atributos quanto à segurança dos alimentos e do meio ambiente, comparativamente àqueles produtos cultivados convencionalmente, nos EUA. Os rótulos investigados indicavam: produto orgânico, orgânico certificado, certificado sem resíduo de agrotóxicos (CSRA) e produtos cultivados com a técnica de manejo integrado de pragas (MIP). Foram entrevistados 1.500 consumidores do Nordeste dos EUA escolhidos ao acaso. Comparativamente ao Censo, os entrevistados possuíam um perfil de idade semelhante, renda levemente mais alta, escolaridade mais alta e sub-representaram os grupos minoritários. Os autores dividiram a amostra em dois grupos: um que recebeu informação sobre os rótulos e outro que não recebeu. Os resultados revelaram que $71 \%$ dos entrevistados consideraram que resíduos de agrotóxicos representam um perigo (de moderado a sério) à saúde dos consumidores. Além disso, $74 \%$ acreditam que eles, também, representam um perigo moderado ao meio ambiente e $64 \%$ os consideram um perigo moderado aos trabalhadores rurais.

Usando modelos lógite, estes autores, concluíram que há um efeito informação positivo sobre a probabilidade de o consumidor comprar, para todos os rótulos, não tendo sido estatisticamente significativo somente para produtos com rótulo de CSRA; o efeito para o rótulo que indicava o uso de MIP na produção foi, sem dúvida, o maior. Os resultados do modelo também mostraram que a probabilidade de comprar produtos com rótulos foi maior para os residentes na cidade do que para os que vivem na 
zona rural ou periferia das cidades, assim como para os consumidores do sexo feminino (maior probabilidade de comprar orgânico e orgânico certificado).

Por outro lado, o estudo de Underhill \& Figueroa (1996) mostrou que, quanto mais velho o consumidor menor a probabilidade de ele comprar produtos rotulados. Testando a interação de variáveis demográficas com a variável informação, os autores encontraram os seguintes resultados: a informação tem um efeito positivo maior sobre os consumidores da zona rural/periferia do que sobre os urbanos. A probabilidade de os primeiros comprarem o rótulo é maior quando informados do que quando não informados e, também, é maior do que a dos consumidores urbanos informados. A interação idade-informação foi negativa, indicando que a informação tem menos efeito sobre os consumidores mais velhos. A existência de uma integração estatisticamente significativa entre sexo e informação diferenciou ainda mais o comportamento das pessoas de sexos diferentes.

Além das variáveis socioeconômicas e demográficas, alguns autores passaram a considerar outras como fatores importantes do processo decisório do consumidor quanto à segurança dos alimentos. $\mathrm{O}$ argumento era de que a decisão do consumidor na compra de alimentos mais seguros ultrapassava a preocupação com seu bem-estar individual, incluindo, também, o bem-estar de sua família. Assim, outras variáveis passaram a incorporar o modelo de decisão do consumidor como, por exemplo, a existência de pessoas de risco na família (crianças, idosos, gestantes e doentes crônicos), como nos estudos de Lin (1995), Huang et al. (1991) e de Dosman (2001).

Lin (1995) pesquisou as influências das características do consumidor sobre a percepção da importância da segurança do alimento na decisão de comprar, usando um modelo próbite para um total de 3.824 famílias dos EUA. Os resultados mostraram que a percepção foi maior para os consumidores do sexo feminino. Quanto mais velho, também mostrou-se mais provável de a segurança do alimento ser importante para o consumidor. Entretanto, a percepção da importância não aumentou monotonicamente com a idade, segundo os resultados. A segurança do alimento mostrou-se mais 
importante para os entrevistados que possuíam pessoas de risco na família, tais como crianças, mulheres grávidas e pessoas mais velhas ( $>64$ anos).

Por sua vez, os resultados de Lin mostraram que houve uma influência positiva, mas decrescente, do número de anos de escolaridade sobre a percepção da importância da segurança do alimento. Segundo o autor, é possível que esse resultado ocorra pelo fato de os mais velhos se considerarem mais preparados para analisar reportagens da mídia e discernir a veracidade do sensacionalismo e, também, por se mostrarem menos aversos ao risco. Os entrevistados que estavam empregados (integral ou parcialmente), na última semana antes da entrevista, mostraram-se menos preocupados com segurança do alimento. Finalmente, a percepção da importância da segurança do alimento para os moradores do Nordeste e Sul dos EUA foi maior do que para outros entrevistados (Meio Oeste e Oeste).

Dosman et al. (2001), além dos fatores socioeconômicos e demográficos, introduziram, em seu modelo, aspectos culturais do consumidor, como preferência político-eleitoral, tipo e nível de emprego e tipo de informação recebida sobre saúde como possíveis fatores determinantes da percepção de consumidores canadenses quanto aos riscos que aditivos, bactérias e agrotóxicos presentes nos alimentos representam para a saúde. Mais especificamente, foram investigadas as seguintes características socioeconômicas dos consumidores: sexo, renda da família, nível de escolaridade, idade, preferência política (eleitoral), tipo e nível de emprego, papel desempenhado na família, número de crianças e adultos na casa e tipo de informação recebida sobre saúde.

Os autores escolheram os entrevistados ao acaso, de uma lista telefônica, em 1994 (1.259) e 1995 (1.241). A variável 'percepção de risco' foi medida por um número discreto ordinal $(0,1,2 \text { ou } 3)^{9}$ e o modelo estimado pelo método próbite ordenado. Os resultados mostraram que as variáveis sexo, renda familiar, número de crianças, idade e

\footnotetext{
${ }^{9}$ Foram apresentadas aos consumidores as seguintes opções de escolha quanto ao grau de risco (y) à saúde associado a alimentos com aditivos, bactérias e agrotóxicos: $y=0$ se nenhum risco à saúde; $y=1$ se risco leve; $y=2$ se risco moderado e $y=4$ se alto risco.
} 
preferência política do entrevistado foram importantes determinantes da percepção dos entrevistados quanto ao risco que aditivos, bactérias e agrotóxicos presentes nos alimentos representam para a saúde. Entretanto, comparando os resultados da amostra de 1994 e de 1995, sexo foi a única variável significativa nos seis modelos (dois anos e três questões de segurança do alimento). A idade, o sexo e a preferência política do entrevistado foram os fatores mais importantes na determinação da sua percepção de risco ligado aos agrotóxicos nos alimentos, nas amostras de 1994 e de 1995. A renda (sinal negativo) foi significativa somente para a amostra de 1994.

A escolaridade dos entrevistados não foi uma variável significativa em nenhuma das amostras do estudo. Os autores aventaram duas hipóteses para explicar esse resultado: a primeira é a de que as pessoas com maior escolaridade entendem melhor os riscos e sabem como evitá-los (ou mitigá-los); a segunda hipótese é a mesma levantada por Lin (1995), ou seja, a de que as pessoas com maior escolaridade sabem interpretar as reportagens da mídia sobre os riscos que alimentos contaminados podem representar para a saúde.

Por outro lado, à medida que cresceram as evidências a respeito de doenças cancerígenas como conseqüência da ingestão de alimentos com resíduos de agrotóxicos, começaram a surgir, na literatura, trabalhos que tratavam dessa questão mais abertamente. Os estudos de Baker (1998), nos EUA, e de Fu et al. (1999), em Taiwan, ilustram esse ponto. Baker usou análise conjunta (conjoint analysis) para medir as preferências dos consumidores quanto aos atributos preço, qualidade determinada pelas características mais visíveis, nível de uso de pesticida/risco de contrair câncer e supervisão do governo, para a maçã Red Delicious. Os usos convencional, reduzido e muito limitado, de pesticida, foram apresentados aos entrevistados como resultando em riscos de respectivamente 1 em cada 1.000, 1 em cada 10.000 e 1 em cada 100.000 , de contrair câncer durante toda a vida. Esse atributo foi consideravelmente o mais importante na decisão dos consumidores de comprar maçã, com um escore de importância relativa de $61 \%$. Os outros três fatores, preço, nível de defeitos e programa 
de certificação, tiveram escore de importância relativa de, respectivamente, 15,14 e $10 \%$.

Fu et al. (1999) estimaram a Disposição (dos consumidores) a Pagar por reduções no risco de contrair câncer associado a resíduos de pesticidas presentes no popular vegetal bok choy, em Taiwan. Pressupôs-se que a probabilidade de se contrair câncer durante a vida, como conseqüência de ingestão de resíduos de pesticidas químicos, via ingestão de bok choy convencional, era de 10 em cada 100.000 pessoas. Foram estimadas as DAPs por reduções de $25 \%, 50 \%$ e $90 \%$ naquele risco. O modelo testou a hipótese de o preço do bok choy, as características demográficas do consumidor, suas atitudes frente aos riscos dos pesticidas, suas condições pessoais de saúde, sua preocupação e percepção quanto à severidade dos riscos dos pesticidas e seu hábito alimentar vegetariano afetarem a DAP por redução no risco de contrair câncer. Os resultados mostraram que indivíduos com doença crônica (condições pessoais de saúde), que compram em supermercados (supostamente com ofertas de vegetais de melhor qualidade), têm maior DAP. A variável preço foi estatisticamente significativa, mostrando relação inversa com a DAP por redução no risco, como era de se esperar. O comportamento mitigador do consumidor, medido pelo hábito de comprar produtos hidropônicos, foi uma variável estatisticamente significativa e positiva, revelando que pessoas que consomem hidropônicos são mais conscientes quanto à saúde. O grau de preocupação com os efeitos de pesticidas (medido pela escala Likert) não foi significativo. Os coeficientes de renda, educação e idade, embora tenham apresentado os sinais esperados, não foram estatisticamente diferentes de zero. Os autores também testaram a sensibilidade da DAP dos consumidores por redução no risco de contrair câncer à magnitude da redução do risco, encontrando coeficiente positivo para a variável, indicando redução de $25 \%$, e negativo para a redução de $90 \%$ no risco, como era de se esperar, ambos estatisticamente significativos a $1 \%$ de probabilidade.

A diferença entre o risco associado ao consumo de hortifrutícolas estimado pelos cientistas (risco objetivo) e aquele estimado pelos consumidores (risco subjetivo) é apontada como uma das possíveis causas do insucesso das políticas governamentais 
relativas à segurança dos alimentos. Parte do problema, argumenta-se, reside na falta de confiança que os consumidores depositam no governo. Estudos como o de Williams \& Hammitt (2001) abordam essa questão, extraindo do consumidor seu julgamento de risco associado ao consumo e produção de produtos hortifrutícolas e identificando os fatores determinantes do mesmo, na região de Boston, nos EUA. Foram estudados os riscos para os consumidores representados pelos resíduos de agrotóxicos, toxinas naturais e microorganismos patogênicos nos alimentos e o risco da exposição dos agricultores aos agrotóxicos. Os resultados de 707 questionários analisados mostraram que os consumidores percebem riscos relativamente altos associados ao consumo de produtos hortifrutícolas, principalmente aqueles representados pelos agrotóxicos, comparativamente a outros riscos à saúde. Muitos consumidores percebem uma redução significativa nos riscos relacionados a pesticidas com a substituição dos hortifrutícolas convencionais pelos orgânicos.

Dentre os vários fatores determinantes investigados por Williams \& Hammitt, a confiança nas agências reguladoras do governo e na segurança da cadeia alimentar foi particularmente importante na explicação da percepção de alto risco dos consumidores. Os autores, com base nesse resultado, recomendam que as agências devem focar sua comunicação em questões mais amplas de credibilidade, lembrando que “a literatura psicológica também sugere que mensagens de risco baseadas somente em avaliações científicas podem não ser aceitas se a fonte de informação é vista como indigna de confiança" (p. 329). Finalmente, os autores declaram que os resultados devem ser vistos com precaução, uma vez que a amostra foi composta por uma proporção muito grande de mulheres, pessoas com alto grau de escolaridade e alta renda segundo a natureza do delineamento da amostra.

Gil et al. (2000) incorporaram, na questão de segurança dos alimentos, outros produtos além dos hortifrutícolas. Os autores estimaram a disposição a pagar por produtos orgânicos (vegetais, batata, cereais, frutas, ovos, frango e carne vermelha) de diferentes segmentos de consumidores, em duas regiões da Espanha: Navarra (região produtora importante) e Madri (importante região consumidora). A segmentação do 
mercado foi obtida usando-se fatores de estilo de vida obtidos por análise de agrupamento (cluster analysis): três grupos em Navarra e quatro em Madri. Variáveis socioeconômicas (idade, sexo, escolaridade, tamanho da família e renda), fatores ambientais e fatores ligados aos produtos orgânicos, obtidos por análise de componentes principais, alem do nível de consumo de orgânicos foram usados para caracterizar cada segmento de mercado.

Os resultados do estudo mostraram que estilos de vida e atitudes frente a questões ambientais foram as variáveis mais importantes para explicar diferenças entre os segmentos de mercado, enquanto as variáveis econômicas foram menos relevantes. Outro resultado interessante do estudo foi o de que somente os prováveis e verdadeiros consumidores de orgânicos mostraram-se dispostos a pagar prêmio pelos mesmos. Além disso, os prêmios foram maiores para vegetais, frutas e carne vermelha comparativamente aos outros produtos estudados e foram também maiores na região produtora (Navarro) do que na região consumidora (Madri).

Huang et al. (1991) e Huang et al.(1999) testaram a hipótese de que o processo de decisão dos consumidores ocorre em várias etapas, ao contrário de uma única, como a maioria dos autores retrata em seus modelos. Huang et al. (1999) investigaram a disposição dos consumidores de Taiwan para pagar um prêmio por vegetais hidropônicos e possíveis fatores socioeconômicos explicativos, dividindo o processo decisório em duas etapas: a primeira, que se referiu à disposição do entrevistado de pagar mais por aqueles produtos e a segunda, de quanto pagar a mais, uma vez decidido a pagar. Foram entrevistados 400 consumidores do sexo feminino, residentes da cidade de Taipei. O levantamento foi delineado para avaliar: a percepção do risco potencial à saúde oferecido por resíduos de agrotóxicos nos alimentos; a avaliação das consumidoras quanto à qualidade e segurança dos alimentos e suas disposição de pagar para reduzir a exposição de sua família à ele . Foi usado um sistema de modelos próbite e próbite ordenado (censurado), estimados conjuntamente, com a finalidade de evitar respostas tendenciosas por parte dos consumidores. Os resultados mostraram que aqueles que tinham crianças pequenas (menores de 12 anos) e mais anos de escolaridade estavam 
dispostos a pagar prêmios mais altos pelos produtos hidropônicos. Por outro lado, consumidores que comiam fora mais de três vezes por semana e que consideravam preço como um fator importante na decisão de comprar mostraram-se menos prováveis de pagar um preço mais alto pelos hidropônicos.

O estudo também revelou que a renda não foi um fator importante na decisão de pagar a mais por hidropônicos (negativa mas não estatisticamente diferente de zero). Os resultados do modelo próbite ordenado, entretanto, mostraram que todas as características socioeconômicas dos consumidores tiveram impactos significativos nas quantias dos prêmios que os entrevistados estariam dispostos a pagar pelos hidropônicos. A probabilidade de pagar prêmios mais altos por hidropônicos foi menor para os entrevistados com crianças pequenas e com maior escolaridade. Também os entrevistados com algum doente crônico na família afetaram positivamente a quantia do prêmio a ser paga pelos hidropônicos. A renda foi significativa, ou seja, uma vez que se decide pagar mais pelos hidropônicos, a quantia do prêmio a ser paga se torna maior em proporção à renda do entrevistado. Os autores mostraram que esses resultados foram, do ponto de vista estatístico, melhores do que os do modelo próbite ordenado único.

Huang et al. (1991) desenvolveram um modelo conceitual, com a finalidade de estudar o comportamento dos consumidores quanto à segurança do alimento relativa ao uso de agrotóxicos na produção de hortifrutícolas. O modelo é recursivo, contendo três hipóteses. A primeira postula que a percepção dos consumidores quanto ao risco que o uso de agrotóxicos na produção de hortifrutícolas pode representar à saúde depende das características socioeconômicas, assim como das crenças, conhecimento e experiência com pesticidas químicos, dos consumidores. A segunda hipótese postula que os consumidores mais prováveis de se posicionarem a favor de medidas mais restritivas (ou até mesmo banimento) em relação ao uso de agrotóxicos (atitude) são aqueles com maior percepção do risco representado pelo uso dos agrotóxicos (primeira hipótese). Além disso, a atitude dos consumidores frente a restrições sobre os agrotóxicos depende de "critérios de avaliação, crenças, e outros fatores relacionados à experiência e satisfação derivadas do consumo de hortifrutícolas in natura" (p. 50). Finalmente, o modelo postula 
que a intenção de pagar um preço mais alto por um produto testado e certificado como não contendo resíduo de agrotóxicos depende da percepção de risco (primeira hipótese) e da atitude com relação ao uso de pesticidas (segunda hipótese), além do preço, freqüência de consumo, presença de idoso, criança ou gestante na família, renda e escolaridade. Os resultados mostraram que as hipóteses quanto às relações que envolvem percepção, atitude e intenção de compra não foram rejeitadas. As crenças, exposição na mídia e preferências foram mais importantes para explicar as variações de percepção, atitude e intenção de compra do que as variáveis socioeconômicas.

$\mathrm{Na}$ tentativa de enriquecer ainda mais a análise do comportamento do consumidor frente à segurança dos alimentos, alguns autores incorporaram diferenças culturais como um fator preponderante do processo decisório dos consumidores. Nesse sentido, os estudos de Lai et al. (1997) e de Jussaume \& Higgins (1998) merecem destaque.

Lai et al. (1997) analisaram a disposição para pagar de consumidores em Atlanta, Georgia, nos E.U.A. e em Berlim, na Alemanha, por atributos de qualidade de vegetais in natura. Variáveis socioeconômicas, demográficas e de atitude (importância do atributo para o consumidor) foram selecionadas como independentes dos modelos próbite ordenados. Os atributos analisados foram: 1) maior teor de fibra; 2) programa de garantia de qualidade; 3) menos nitrato e 4) menos resíduos químicos. Os resultados mostraram que os consumidores, geralmente, tiveram uma percepção positiva do assunto da entrevista, tendo a maioria se disposto a pagar mais pelos quatro atributos, sendo que os de Berlim se mostraram mais favoráveis ao assunto da entrevista do que os de Atlanta. Somente em Berlim diferenças nos fatores socioeconômicos e demográficos dos consumidores afetaram a disposição para pagar mais por alimentos com níveis mais baixos de resíduos químicos; entre esses fatores, as classes de renda mais alta e os estudantes apresentaram probabilidade mais alta de pagar mais do que os de baixa renda. Segundo os autores, o desenvolvimento de vegetais com mínimo resíduo químico e um sistema de rastreamento de resíduo irá encorajar os consumidores de renda mais alta de Berlin a pagar um prêmio por vegetais in natura. 
Jussaume \& Higgins (1998) também testaram a hipótese de que a preocupação dos consumidores relativa à segurança dos alimentos, nos EUA e no Japão, está inserida num contexto maior do que o usualmente considerado nos estudos de segurança do alimento, ou seja, num contexto em que também estão presentes preocupações com o meio ambiente não diretamente relacionadas à produção de alimentos. Assim, os autores testaram a hipótese de a preocupação dos consumidores com segurança de alimentos estar relacionada a comportamentos pró-ambientais, além de variar de acordo com os fatores representados por condições demográficas, socioeconômicas e de confiança do consumidor no sistema alimentar. Os resultados mostraram que das 21 variáveis independentes consideradas, somente duas, 'país de residência' e 'consumo moderado de vegetais' explicaram a variância da medida 'preocupação com segurança do alimento'. Ou seja, a probabilidade de japoneses residentes e famílias que consumiam uma variedade moderada ou alta de vegetais se preocuparem com segurança do alimento foi maior, resultado encontrado em estudo anterior (Jussaume \& Judson, $1992^{10}$, citado por Jussaume \& Higgins, 1998). Em dois dos modelos estimados, a variável 'Governo faz um bom trabalho em garantir a segurança do alimento' foi significativa porém com sinal negativo. Isso significa que o interesse do consumidor em questões de segurança do alimento está relacionado à falta de confiança na habilidade de garantia de uma oferta de alimentos seguros. Finalmente, os autores testaram e não rejeitaram a hipótese de que pertencer a um grupo (EUA ou Japão) afeta a relação entre variáveis independentes e variável dependente. Os resultados mostraram que os japoneses se mostraram significativamente mais preocupados com a segurança dos alimentos e com maior probabilidade de se tornarem membros associados de uma cooperativa de consumidores, "proxy" usada para medir o comportamento do consumidor na tentativa de comprar alimentos seguros.

\footnotetext{
${ }^{10}$ JUSSAUME, R.A.Jr.; JUDSON, D.H. Public Perception about food safety in the United States and Japan. Rural Sociology, v.7, p.235-249, 1992.
} 
A revisão desses estudos mostrou que muito se progrediu na determinação dos fatores que afetam o comportamento do consumidor frente ao risco que alimentos contendo resíduos de agrotóxicos representam para a saúde humana. A teoria neoclássica já reconheceu, por meio da teoria de Lancaster (1971), que a utilidade obtida pelo consumidor provém não somente das quantidades consumidas dos bens e serviços, mas, também, de outros atributos ligados aos mesmos. Assim, o indivíduo não obtém utilidade somente a partir da quantidade de alimento que ingere, mas, também, da presença de outras pessoas à mesa, do visual proporcionado pelo alimento, da música ambiente que possa estar presente etc. Ainda que tenha sido uma contribuição importante, a teoria de Lancaster não incluiu o bem-estar de outros consumidores como um dos possíveis determinantes da decisão do consumidor individual. Sob esse aspecto, o consumidor continuou a ser visto como um indivíduo egoísta.

Os estudos revistos, entretanto, rejeitam essa visão egoísta do consumidor quando se trata de decidir o consumo de alimentos que podem representar algum risco à saúde humana, principalmente daqueles que contêm resíduos de agrotóxicos. Nesse aspecto, houve grande progresso na literatura. Entretanto, pode-se dizer que praticamente toda essa literatura se encontra concentrada nos países desenvolvidos. Dos estudos aqui revistos, além dos brasileiros, somente os de Fu et al. (1999), Huang et al. (1999) e de Akgüngör et al. (1999), foram conduzidos em países em desenvolvimento. No Brasil, destacaram-se a Pesquisa ... (1991), sobre hábitos alimentares no Brasil, e os trabalhos de Spears \& Kassouf (1996), Fazio et al. (1997), Spears (1998), Cerveira \& Castro (1999). Nenhum desses estudos, entretanto, investigou possíveis determinantes da disposição a pagar de consumidores brasileiros por alimentos sem resíduos de agrotóxicos. Investigálos significa, acima de tudo, começar a conhecer o comportamento dos consumidores brasileiros com relação a esse problema, o que, se espera, contribua para maior eficácia das políticas de saúde pública e de tecnologia agropecuária. É o que pretende este estudo ao estimar a disposição a pagar mais por hortifrutícolas sem agrotóxicos de uma amostra de consumidores de Piracicaba, no Estado de São Paulo. 


\section{MATERIAL E MÉTODOS}

Neste capítulo são apresentados os elementos teóricos que orientaram o estudo, organizados em cinco itens. O primeiro trata do referencial teórico; o segundo, da especificação do modelo econométrico estimado. A definição das variáveis usadas no modelo se encontra no terceiro item. No quarto, é caracterizada a área de estudo. $\mathrm{O}$ quinto apresenta a técnica de levantamento e finalmente, é feita a caracterização da pesquisa de campo, da seleção dos entrevistadores à definição final da amostra do estudo.

\subsection{Embasamento teórico}

Embora tenham crescido substancialmente no mercado, nos últimos anos, e influenciado muitas pesquisas na área de segurança do alimento, os produtos sem agrotóxicos ainda representam um segmento muito pequeno do mercado de alimentos no mundo (Gil et al., 2000). Em suma, este mercado é pequeno e os produtos não estão largamente distribuídos no comércio varejista. Por essa razão, o método de valoração contingente (MVC), normalmente empregado para avaliar monetariamente os bens não transacionados no mercado (recursos naturais), tem sido largamente utilizado para estudar a disposição de pagar por segurança do alimento (food safety), particularmente no que se refere à presença de resíduos de agrotóxicos. 
Os conceitos e derivações do método de valoração contingente estão suficientemente generalizados, não sendo necessário repeti-los neste trabalho ${ }^{12}$. O que se apresentará, a seguir, são as passagens julgadas essenciais para o acompanhamento do raciocínio aqui desenvolvido para contemplar a solução do problema proposto neste estudo envolvendo os HSA.

O método de valoração contigente (MVC) permite extrair um valor monetário que expressa a variação no nivel de bem-estar dos consumidores devido a uma alteração no desfrute direto ou indireto de um bem ou serviço. A concepção de determinação deste valor monetário foi proposta por Hanemann (1984) a partir de uma função de utilidade indireta. Imaginando-se um consumidor, nos moldes da teoria neoclássica, que busca sempre maximizar a satisfação de suas necessidades, por meio do consumo de bens e serviços sujeito a um dado nível de renda, e supondo que o indivíduo derive sua utilidade de modo que suas preferências possam ser representadas por uma função de utilidade indireta. A formulação do autor, aqui com simbologia adaptada de Brugnaro (2000), é:

$$
u(y, r \mid \omega)
$$

onde, para representar o consumo de HSA, uma variável binária y é introduzida. Desta forma, $y=1$ se o indivíduo consome HSA; caso contrário, $y=0$. A renda do indivíduo é representada por $r$ e $\omega$ é um vetor de atributos e características individuais que poderiam afetar sua preferência. Portanto, a utilidade do indivíduo é $u_{I}=(1, r \mid \omega)$ se ele consome HSA; caso contrário, $u_{0}=(0, r \mid \omega)$.

O modelo de Hanemann pressupõe que o consumidor conhece a sua função de utilidade com certeza. Entretanto, ao pesquisador alguns dos seus componentes não são observáveis sendo, portanto, considerados como estocásticos. Segundo o autor,

\footnotetext{
${ }^{12}$ Sobre este assunto ver, por exemplo os trabalhos de Hanemann (1984), Mitchel \& Carson (1989), importantes contribuições teóricas ao método e as aplicações do método a problemas brasileiros em Belluzzo Jr (1995), Aguirre \& Faria (1996), Mota (1998), Ribeiro (1998) e Brugnaro (2000).
} 
"esses componentes servem para gerar a estrutura estocástica do modelo estatístico de resposta binária"(p. 333).

Assim, $u_{0}$ e $u_{l}$ são consideradas variáeis aleatórias com determinada distribuição de probabilidade e médias $v(1, r \mid \omega)$ e $v(0, r \mid \omega)$, podendo, assim, ser representadas por:

$$
u(y, r \mid \omega)=v(y, r \mid \omega)+\varepsilon_{y} \quad y=0,1
$$

em que $\varepsilon_{0}$ e $\varepsilon_{l}$ são variáveis aleatórias independentes e identicamente distribuídas com médias iguais a zero.

Então, o consumidor dispõe-se a pagar um preço $p$ pelo consumo de HSA caso ocorra:

$$
v(1, r-p \mid \omega)+\varepsilon_{1}>v(0, r \mid \omega)+\varepsilon_{0}
$$

Assim, para o pesquisador, a resposta do entrevistado é uma variável aleatória cuja distribuição de probabilidade é dada por:

$$
\begin{aligned}
& \pi^{s}=\operatorname{prob}\{\text { individuo se dispor a pagar pelos } \mathrm{HSA}\}= \\
& \operatorname{prob}\left\{v(1, r-p \mid \omega)+\varepsilon_{1}>v(0, r \mid \omega)+\varepsilon_{0}\right\} \\
& \pi^{n}=\operatorname{prob}\{\text { indivíduo não se dispor a pagar } p \text { pelos } \mathrm{HSA}\}=1-\pi^{*}
\end{aligned}
$$

Seja $\delta=\varepsilon_{0}-\varepsilon_{1}$ e $F_{\delta}($.$) a função de distribuição acumulada de \delta$. Assim, a probabilidade de o consumidor se dispor a pagar $p$ pelos HSA pode ser escrita como

$$
\pi^{s}=F_{\delta}(\Delta v)
$$

em que: $\Delta v=v(1, r-p \mid \omega)-(0, r \mid \omega)$

No lógite, $F_{\delta}($.$) é a função de distribuição acumulada de uma variável$ logística, usada neste estudo: 


$$
F_{\delta}(\Delta v)=\left(1+e^{-\Delta v}\right)^{-1}
$$

Segundo Byrne et al. (1994), econometricamente a análise do lógite é superior à do próbite porque a proposição de normalidade deste último não é muito forte. Ainda, esses autores argumentam que o processo lógite capta melhor a magnitude dos efeitos da variável dependente. Por essa razão, o modelo lógite foi adotado neste trabalho.

$\mathrm{O}$ argumento de $F_{\delta}($.$) deve sęr o resultado da diferença de utilidades como$ em (6). Por exemplo:

$$
v(y, r \mid \omega)=\alpha_{y}+\beta r \quad \beta>0 \quad y=0,1
$$

Suprimindo-se o vetor $\omega$, tem-se:

$$
\Delta v=\left(\alpha_{I}-\alpha_{0}\right)-\beta p
$$

Assim, o modelo estatístico de escolha se torna:

$$
\pi^{s}=F_{\delta}(\alpha-\beta p) \text { onde } \alpha=\alpha_{I}-\alpha_{0}
$$

\subsection{Especificação do modelo a ser estimado}

Como a equação (10) envolve um problema de otimização e estando baseada numa função de logística adota-se o procedimento de estimação pelo método de máxima verossimilhança. Maiores detalhes podem ser observados em Judge et al. (1998).

A equação (10) ajustada pelo método de máxima verossimilhança, e empregada nesta pesquisa tem a seguinte forma funcional: 


$$
\begin{aligned}
\log \left[\frac{\pi^{*}}{\left(1-\pi^{*}\right)}\right] & =\beta_{0}+\beta_{1} x_{1}+\beta_{2} x_{2}+\beta_{3} x_{3}+ \\
& +\beta_{4} x_{4}+\beta_{5} x_{5}+\beta_{6} x_{6}+\beta_{7} x_{7}+\beta_{8} x_{8}+ \\
& +\beta_{9} x_{9}+\beta_{10} x_{10}+\beta_{11} x_{11}+\beta_{12} x_{12}+ \\
& +\beta_{13} x_{13}+\mu \\
& =\beta_{0}+\sum_{i=1}^{n} \beta_{i} x_{i}+\mu
\end{aligned}
$$

onde: $\ln \left[\frac{\pi^{s}}{\left(1-\pi^{s}\right)}\right]$ é chamada de transformação logística (ou lógite): é o logaritmo natural da relação entre a probabilidade de aceitação $\left(\pi^{\mathrm{s}}\right)$ e a probabilidade de não aceitação $\left(1-\pi^{5}\right)$; é a variável dependente na equação de regressão; $x_{i}$ é um vetor de variáveis explicativas relacionadas ao consumidor e $\beta$ o correspondente vetor de parâmetros.

\subsection{Definição das variáveis}

\subsubsection{Variável dependente:}

(DAP): disposição de pagar - variável dependente no modelo, não assumindo valores contínuos. Ela representa uma resposta binária dos indivíduos, assumindo valor 1 se o entrevistado está disposto a pagar mais por HSA frescos que apresentem um selo alegando ausência de resíduos de agrotóxicos; igual a 0 , caso contrário;

\subsubsection{Variáveis explanatórias}

(( $\mathbf{X}_{1}:$ Preço): foi solicitado aos entrevistados que classificassem as três maiores preocupações com alimentos de uma lista de 10 itens que incluía a afirmativa 
"preço". Se o "preço" fosse considerado entre as três maiores preocupações do entrevistado, na hora da compra de hortifrutícolas, assumiria o valor $1 ;=0$, caso contrário. Esta variável segue a forma proposta por Huang et al (1991).

$\left(\mathrm{X}_{2}\right.$ :Teste/governo): esta variável está subentendida como uma alternativa de certificação que assegure uma melhor segurança do alimento para os consumidores. Assim, esta variável assumiu o valor 1 no caso de o entrevistado respondesse que caberia ao governo a responsabilidade de testar e certificar os alimentos como livres de agrotóxicos. Caso contrário, se afirmasse que esse encargo deveria ser assumido por laboratórios privados, associações de produtores, ou quem comercializa seria zero. Quanto ao sinal esperado do coeficiente desta variável, não existe, em princípio, uma constatação prévia que permita formar expectativas a seu respeito.

( $\mathrm{X}_{3}$ :Grupo de risco): definida igual a 1 , se algum membro da família do entrevistado, que vive na sua casa, for gestante e/ou idoso e/ou criança e/ou apresenta algum tipo de doença crônica; e igual a 0 , caso contrário. Acredita-se que este subgrupo da população seja mais vulnerável aos efeitos dos problemas oriundos dos agrotóxicos em sua alimentação'. Hamilton $(1985)^{13}$, citado por Dosman (2001), observou que as mulheres que tinham crianças em casa eram as mais preocupadas com problemas do meio ambiente, enquanto que os homens sem crianças foram os menos preocupados. Para essa variável acredita-se ocorrer uma relação positiva, entre os pertencentes a este segmento familiar, quanto `a disposição de pagar por HSA.

( $\mathrm{X}_{4}$ :Linha de pobreza): a renda pessoal ou familiar tem importante influência sobre os hábitos de consumo dos indivíduos. Acredita-se que à medida que a renda cresce, propicia aos consumidores a aquisição de produtos que diminuem sua exposição aos níveis de riscos. Nesta pesquisa, esta variável é binária e foi construída a partir do valor do rendimento mensal familiar per capita. Assumiu o valor 1 para valores

13 HAMILTON, L.C. Concern about toxic wastes: three demographic predictors. Sociological Perspectives, v.28, p.446-486, 1985. 
menores ou iguais a meio salário mínimo $(\mathrm{Cr} \$ 90,00)$ e 0 caso contrário. Para esta variável pressupõe-se um sinal positivo, uma vez que quanto menor a renda, menor a disposição de pagar por HSA.

( $\mathrm{X}_{\mathbf{5}}$ :Idade): idade do entrevistado em anos. A idade pode afetar positivamente o modo como o entrevistado percebe os riscos para a saúde oferecidos pelos alimentos, ou seja quanto mais velho maior a sua percepção. Entretanto, os resultados observados para esta variável tem sido contraditórios. De acordo com Dosman et al (2001) se a idade cresce, aumenta a percepção do risco monotonicamente. Segundo, Lin (1995) a idade foi positivamente correlacionada com a importância da segurança do alimento até determinado ponto (certa idade). Neste caso, não foi verificado uma relação monotônica. Já para Underhill \& Figueroa (1996) quanto mais velho diminui a probabilidade de compra dos produtos rotulados. Para esta variável, não há uma base prévia que permita formar expectativas quanto à natureza do sinal de seu coeficiente.

( $\mathrm{X}_{5}:$ Idade2): é a idade do entrevistado ao quadrado. Com o auxílio desta variável, pode-se observar a existência ou não de efeitos não lineares da idade sobre a disposição de pagar por HSA à medida que ocorre o aumento da idade do entrevistado.

$\left(\mathbf{X}_{6}:\right.$ Atitude): ${ }^{14}$ afirmativas descrevendo as atitudes que poderiam ser tomadas para garantir a segurança na produção de hortifrutícolas frescos, quanto ao uso de agrotóxicos, foram fornecidas aos entrevistados. Pediu-se que selecionassem uma afirmativa como a que melhor expressasse sua opinião sobre o uso de agrotóxico. Assim, a variável atitude assumiu o valor 1 , se o entrevistado selecionou "todos os agrotóxicos deveriam ser proibidos definitivamente ou os que não são seguros deveriam ser proibidos definitivamente e os restantes deveriam sofrer maiores restrições"; ao contrário, a variável assumia valor 0 . Neste caso, o uso atual dos agrotóxicos não é visto como um problema pelo entrevistado. Esse foi procedimento adotado por Huang et al

\footnotetext{
${ }^{1+}$ De acordo com Engel et al $(1999$, p.93) "uma atitude é simplesmente a avaliação geral de uma alternativa, variando de positiva a negativa".
} 
(1991). Para esta variável cogita-se um coeficiente positivo, retratando uma disposição a pagar por HSA.

$\left(\mathrm{X}_{7}:\right.$ Percepção de risco): ${ }^{15}$ pediu-se aos entrevistados que apontassem as três maiores preocupações com alimentos de uma lista de 10 itens que incluíram a afirmativa "produtos cultivados com agrotóxicos". Dessa forma se "produção com uso de agrotóxicos" foi incluída entre as três maiores preocupações do entrevistado na hora da compra de hortifrutícolas assumiu o valor $1 ;=0$, caso contrário. A forma de concepção dessa variável também se baseou em Ott (1991) e Huang et al (1991). É aguardada uma correlação positiva com a disposição a pagar por HSA.

( $\mathrm{X}_{8}$ :Escolaridade): anos de estudo do entrevistado.O nível de instrução dos entrevistados pode influir na percepção dos riscos embutidos nos hortifrutícolas produzidos com agrotóxicos. Acredita-se que indivíduos com níveis mais altos de escolaridade possam ter uma melhor compreensão dos riscos potenciais dos alimentos. Entretanto, os resultados obtidos em diversos estudos não são convergentes. Uma excelente revisão a esse respeito pode ser vista em Dosman et al. (2001).

( $\mathrm{X}_{9}$ :Dieta): pressupõe-se para esta variável o valor igual 1 , se o entrevistado faz tipo de dieta para emagrecimento. Caso contrário, zero. Acredita-se que os entrevistados que se submetem a dieta de emagrescimento possuem uma alimentação mais rica em vegetais e frutas, e desta forma estariam mais expostos aos riscos dos resíduos químicos. Nestas circunstâncias, é esperado um sinal positivo para o coeficiente desta variável.

( $\mathrm{X}_{11}$ :Planejador principal): foi designado para esta variável o valor 1 , se 0 entrevistado é quem decide o que a família deve comer. Caso contrário, zero. Segundo Lin (1995), um planejador da refeição principal pode ser considerado como a "dona de casa" que seleciona e determina o conteúdo e prepara e consumo os alimentos a serem

\footnotetext{
${ }^{15} \mathrm{Na}$ verdade segundo Huang et al, (1991, p.50), "a percepção representa a informação que o indivíduo possui sobre o objeto" que nesse estudo são os resíduos der agrotóxicos nas verduras, legumes e frutas frescas.
} 
consumidos, que por sua vez, o afetam e afetam os membros da sua família. Para esta variável, não há uma base prévia que permita formar expectativas quanto à natureza do sinal de seu coeficiente.

$\left(\mathrm{X}_{12}\right.$ : Consumo): para esta variável foi atribuído o valor 1 , se o consumo de verduras, legumes e frutas frescas do entrevistado aumentou nos últimos 6 meses. Caso contrário, zero. Para esta variável associa-se uma maior (menor) exposição aos efeitos dos agrotóxicos em decorrência de um aumento (decréscimo) no consumo.

(( $\mathrm{X}_{13}$ :Informação): com esta variável busca-se observar o poder de compreensão dos entrevistados sobre a natureza dos produtos cultivados sem agrotóxicos. Desta forma, para esta variável foi atribuida o valor 1 , se o entrevistado respondeu que somente produto orgânico, hidropônico, natural e agroecológico são produzidos sem agrotóxicos, a partir das opções que lhe foram apresentadas. Assumiu o valor zero em caso de escolha de outra opção oferecida. Aqui, é aguardado um sinal positivo para o coeficiente desta variável..

\subsection{Caracterização da área de estudo}

Piracicaba, cuja população é estimada em 308.631 habitantes, tem, aproximadamente, $95 \%$ de sua população residindo na área urbana (FIBE, 1995). O Município consolidou-se como importante centro de produção de cana-de-açúcar, em torno do qual formou-se importante complexo industrial. Hoje, o setor industrial apresenta-se bastante diversificado, com predomínio de estabelecimentos voltados para a produção de equipamentos destinados à indústria sucro-alcooleira. O Município aglutina expressivo comércio atacadista e varejista, com estabelecimentos de origem local, além de lojas de departamentos nacionais, atraindo consumidores de cidades vizinhas, em um total de, aproximadamente um milhão de pessoas. Destaca-se, desta forma, como um pólo regional de desenvolvimento (Piracicaba, 1996). 


\subsection{Técnicas de levantamento}

As técnicas de levantamento são instrumentos tão importantes como os questionários na orientação de qualquer pesquisa.

No procedimento de realização da pesquisa de campo, o total de recursos e o tempo disponível, para se realizar a pesquisa, acabam por influenciar a escolha da técnica (Brugnaro, 2000). O tempo exigido para as respostas pode variar muito se os respondentes têm alguma afinidade ou nenhuma experiência sobre o bem ou serviço em análise. Por sua vez, dado o seu desconhecimento do teor da entrevista, os consumidores podem negar-se a participar da pesquisa, alegando, principalmente, falta de tempo.

O levantamento por telefone é outro modo de se buscar informações por parte dos consumidores. É um processo de custo relativamente mais baixo que as outras técnicas. Porém, pode apresentar alguns inconvenientes, como o da ausência de contatos visuais na descrição do problema e o da exclusão de parte da população que não tem acesso a telefones (Mitchell \& Carson, 1989).

A coleta de informações, por meio do envio de questionários pelo correio, tem as vantagens de propiciar ao respondente mais tempo para avaliar e decidir o que está sendo proposto. Dentre as desvantagens estão o tempo de espera, a baixa expectativa de retorno dos questionários e o risco de preenchimento incorreto. A seriedade das respostas está condicionada à compreensão que o respondente tem do das perguntas formuladas, o que é no mínimo, temerário frente o grau de instrução e habilidade de leitura de grande parte da população brasileira.

A técnica que pode proporcionar uma melhor compreensão das questões, bem como uma maior interação com os respondentes, é a entrevista face a face. Uma das alternativas desse tipo de entrevista é a abordagem em pontos de fluxo de pessoas. Para estimar a disposição de pagar por redução da poluição de um rio em Goiás (Brasil), Ribeiro (1998) utilizou esta técnica entrevistando pessoas que estavam comprando ou portavam hortaliças nas feiras livres. Brugnaro (2000) também para estimar o valor 
monetário do recurso ambiental representado pelas matas ciliares da Bacia do Rio Corumbataí, em São Paulo entrevistou os cidadãos na via pública. Ott (1990), Fu et al. (1999) estimaram a disposição a pagar por vegetais frescos livres de resíduos químicos por meio de entrevistas nos supermercados de Atlanta (EUA) e Taiwan. Esta é a técnica a ser empregada nesta pesquisa, embora se reconheçam algumas dificuldades de permissão e acesso aos estabelecimentos comerciais para entrevistas e algum tipo de viés que o questionário venha apresentar.

\subsection{Caracterização da pesquisa de campo}

A busca dos dados relevantes para o empreendimento desta pesquisa contou com a colaboração de entrevistadores (sete moças e três rapazes), recrutados entre os estudantes de graduação dos cursos de Engenharia Agronômica e Economia Agroindustrial da ESALQ/USP. Os dados foram obtidos por meio de entrevistas pessoais com consumidores presentes nos locais de compra de produtos hortifrutícolas na cidade de Piracicaba, em São Paulo. Embora alguns estudantes do grupo tivessem vivenciado trabalhos desta natureza, todos foram submetidos a um processo de capacitação e treinamento (comportamento durante a abordagem e a entrevista; procedimentos para a escolha aleatória de pesssoas a serem abordadas etc), preconizado por Oliveira (1998).

O passo seguinte foi submeter o questionário elaborado (Anexo A) para o estudo a um pré-teste, para que fossem corrigidas eventuais falhas do mesmo. Segundo Marconi \& Lakatos (1998), o pré-teste serve para verificar se o questionário apresenta três importantes elementos: fidedignidade - qualquer pessoa que o aplique obterá os mesmos resultados; validade - os dados recolhidos são necessários à pesquisa; operatividade - vocabulário acessível, significativo e claro. Nessa etapa, foram realizadas 40 entrevistas. A escolha dos locais das entrevistas foi arbitrária, sem maior rigor quanto à sua aleatoriedade, não deixando de lado, entretanto, os bairros onde poderiam se encontrar as populações mais carentes. $O$ fato de alguns acadêmicos terem tido experiências anteriores contribuiu de forma positiva para o ajuste dos formulários, 
do ponto de vista da liguagem e da ordem de apresentações das questões e quadramento dos demais participantes neste tipo de trabalho de campo. Os dados originais se encontram disponíveis aos interessados.

O dimensionamento da pesquisa definitiva partiu de um referencial de 330 entrevistas realizadas em diferentes estabelecimentos comerciais localizados nos diversos bairros da cidade de Piracicaba, durante os meses de abril a maio de 2002. Os fatores financeiros e o tempo disponivel para a concretização deste estudo foram fatores preponderantes para o dimensionamento dessa amostra.

A escolha dos locais de entrevistas (sacolões, quitandas, mercados e supermercados) foi feita com base na lista telefônica, seção 'Supermercados' da cidade de Piracicaba (Listel, 2001). Ainda, integraram este quadro informações provenientes da Secretaria de Abastecimento da Prefeitura do Municípo. Foram listados todos os estabelecimentos e sua localização (bairro, rua, número e telefone). Em seguida, com posse de um mapa, a cidade foi dividida em seis regiões, englobando todos os 62 bairros com os seus diversos pontos de venda de produtos hortifrutícolas.

O número de entrevistas em cada bairro foi ponderado pela populaçãa ${ }^{16}$ nele residente e centrado nos pontos de comercialização de hortifrutícolas, seguindo o pressuposto básico de que os consumidores fazem as compras daqueles produtos nos próprios bairros em que residem. Em caso da verificação de não existência do estabelecimento no local, o entrevistador dirigiu-se ao estabelecimento mais próximo.

Os entrevistados foram escolhidos aleatoriamente utilizando-se o mesmo esquema de abordagem. Ainda, foi enfatizado que não era necessária à identificação do entrevistado e que toda a informação coletada estaria sujeita a um tratamento global e anônimo.

\footnotetext{
${ }^{16}$ O número de bairros e a população residente foram obtidos junto a Secretaria de Planejamento do Município.
} 


\section{RESULTADOS E DISCUSSÃO}

Este capítulo apresenta e discute os resultados do estudo. Em primeiro lugar, procede-se à análise do perfil da amostra. Em seguida, apresenta-se e discute-se os resultados obtidos da estimação do modelo econométrico usado.

\subsection{Perfil da amostra}

Dos 330 questionários respondidos nas entrevistas, foram descartados 16 , por preenchimento incompleto (alguns dos entrevistados não sabiam, estavam desempregados ou se negaram a informar a renda familiar). Assim, a amostra remanescente, para critérios de análise, foi composta por 314 observações, com a maioria dos entrevistados (77\%) alegando residir nas imediações dos estabelecimentos comerciais e feiras pesquisadas. Os supermercados destacaram-se como locais de compra de preferências dos consumidores, concentrando $86 \%$ das entrevistas.

Do total dos entrevistados, 217 eram do sexo feminino e 97 do sexo masculino, o que corresponde respectivamente a $69 \%$ e $31 \%$ do total pesquisado. A participação de pessoas do sexo feminino ficou aquém do esperado. Esperava-se uma maior presença das mulheres (donas de casa) neste tipo de levantamento. Como apontado por Stager \& Witte ${ }^{17}$, citados por Lin (1995), tem sido sugerido na literatura que as mulheres são mais preocupadas com a saúde humana do que os homens porque elas dão à luz e são socializadas para nutrir e manter a vida. Acredita-se que uma das razões para um menor envolvimento dos entrevistados do sexo feminino possa ser

${ }^{17}$ STAGER, M.A.; WITTE, S.L. General differences in environmental orientations: a comparison of publics and activists in Canada and de U.S. The Western Political Quartely, v.42, p.627-49, 1989. 
explicado pelo aumento da tendência de maior inserção da mulher no mercado de trabalho, o que exige maior engajamento dos homens nos afazeres domésticos, inclusive compras em supermercados. A data (dia da semana) e o horário das entrevistas também podem ter interferido neste resultado.

Neste levantamento, foi constatado que a média de idade dos entrevistados foi de aproximadamente 43 anos. A Figura 7 apresenta a distribuição e a participação relativa dos participantes da pesquisa, em cada faixa etária. Como se pode observar, $83,4 \%$ deles tinham de 21 a 60 anos de idade, com quase $70 \%$ do total da amostra na faixa etária de 21 a 50 anos.

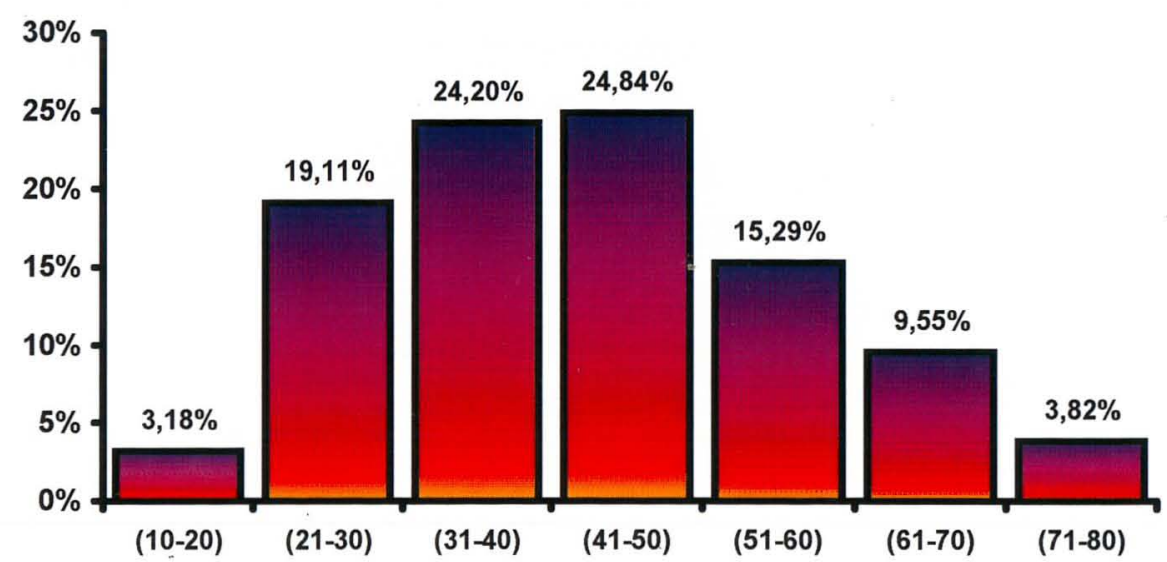

Figura 7 - Distribuição de freqüência dos entrevistados por faixa etária.

A pesquisa de campo mostrou uma escolaridade média dos entrevistados de 8,7 anos. Esse dado contrapõe-se às médias estadual e nacional que são respectivamente de 7,1 e 6,1 anos (PNAD, 1998).

A renda média familiar mensal da amostra foi da ordem de $\mathrm{R} \$ 1.638,00$. Comparando-se esse valor com o valor geralmente usado para delimitar a linha de pobreza da população (de meio salário mínimo - R\$ 90,00 na época do levantamento da 
pesquisa), conclui-se ser o mesmo extremamente alto. Como já enfatizado, a pesquisa foi realizada em vários estabelecimentos comerciais de diversos bairros da cidade. Contudo, apesar de aleatória, a amostra ficou caracterizada, na média, por indivíduos com alta renda e alto grau de instrução, o que, mais uma vez, não surpreende por se referir ao estado mais rico da União.

Um número expressivo de entrevistados (274), ou 87\% da amostra, alegaram ter conhecimento de que os produtos hortifrutícolas, em geral, podem apresentar resíduos de agrotóxicos. Ainda, 229 entrevistados (73\%) escolheram adequadamente o nome dos produtos cultivados sem agrotóxico, face às opções apresentadas. Todavia, 19\% não sabiam o que era um produto orgânico e $8 \%$ opinaram de forma incorreta sobre ele. A mídia, de um modo geral, foi citada como uma das principais fontes de acesso a esse tipo de informação. As outras, menos expressivas, foram: "os amigos", "ouviu falar", "aparência e sabor", "já fui agricultor", "profissional da área", "contato com pesquisa" e "local de venda".

Os entrevistados também foram avaliados em relação à sua percepção de risco. Neste estudo, considerou-se que o consumidor tinha "percepção do risco" representado pelos produtos hortifrutícolas com resíduos de agrotóxicos se essa fosse uma das suas três principais preocupações no momento da compra. Os resultados mostraram que apenas $14 \%$ dos entrevistados inclúram a produção com uso de agrotóxico dentre as três maiores fontes de preocupação na hora de adquirir hortifrutícolas. Ainda, para esses consumidores amostrados, dentre as três principais preocupações na hora da compra aparecem: a aparência do produto $(52 \%)$, valor alimentar $(43 \%)$, preço $(39 \%)$ e presença de conservantes e aditivos $(10 \%)$. Estes fatos deixam transparecer, num primeiro momento, que os consumidores ao priorizarem a aparência dos produtos, indiretamente aceitam a presença dos agrotóxicos na produção destes alimentos.

$\mathrm{Na}$ tentativa de avaliar o grau de consciência dos consumidores quanto ao risco relativo dos alimentos contaminados com agrotóxicos houve uma pergunta que 
constatou que apenas 94 dos investigados (30\%) consideraram o risco de serem assaltados menor do que o risco de comer hortifrutícolas contaminados com agrotóxicos. Em outras palavras, a maioria $(60 \%)$ considera ser assaltado mais arriscado do que o de comer alimento contaminado. Tal fato não surpreende, principalmente devido aos altos índices de violência presenciados atualmente pela sociedade brasileira e ao fato de os efeitos provocados pelos resíduos químicos, na maioria das vezes, somente se manifestarem no médio e longo prazos.

Os entrevistados também foram indagados sobre suas experiências com o uso de químicos em hortas, jardins e vasos domésticos, venenos, como raticidas, assim como com realização de dedetizações em suas residências. Embora não conclusivos, estudos anteriores testaram o efeito dessa experiência sobre o comportamento dos consumidores relativamente aos alimentos com agrotóxicos (Sachs et al., 1987; Cox, 1999). Cox chama a atenção, em seu trabalho, para os perigos envolvendo os inertes ${ }^{18}$. Através de um relato de uma dedetização caseira em NovaYorque, esta autora explica como os inertes põem em risco a saúde das pessoas. Neste trabalho, mais da metade dos entrevistados (57\%) afirmou fazer uso de algum tipo dessas substâncias químicas. O surto de dengue, no Brasil e no município de Piracicaba, em particular, durante o levantamento dos dados, pode ter influenciado os resultados.

Como exposto no capítulo de metodologia, alguns grupos da população apresentam maior susceptibilidade a doenças em geral (crianças, idosos e portadores de doenças crônicas graves) enquanto outros grupos, por consumirem mais hortifrutícolas, estão mais expostos aos resíduos de agrotóxicos. O estudo considerou essas pessoas como pertencentes a um grupo de risco, pressupondo que a presença de qualquer um deles afeta positivamente o consumo de hortifrutícolas sem agrotóxicos, caracterizando o aspecto 'altruísta' do consumidor que se preocupa não somente com o seu mas também com o bem-estar de seus familiares, o que contraria os pressupostos da teoria

\footnotetext{
${ }^{18}$ São quaisquer ingredientes de pesticidas que não um ingrediente ativo (Cox, 1999).
} 
neoclássica do comportamento do consumidor. Assim sendo, foi perguntado aos entrevistados se existiam crianças, gestantes, idosos, portadores de doenças crônicas graves ou pessoas que fazem dieta, em casa. A maioria dos respondentes (65\%) confirmou a presença de criança, gestante ou idoso em casa. Apenas $13 \%$ dos entrevistados afirmaram possuir alguém com algum tipo de doença crônica em casa e $35 \%$ afirmaram fazer algum tipo de dieta (regime).

Neste levantamento, a opinião quanto a importância do selo de certificação dos produtos sem agrotóxicos e a quem caberia a responsabilidade de emití-lo também foi captada pelos entrevistados. Os consumidores, em quase sua totalidade (95\%), alegaram ser importante que os produtos fossem testados e que apresentassem um selo comprovando ausência de resíduos de agrotóxicos. Contudo, quando questionados sobre quem deveria emitir tal certificado, 102 entrevistados responderam ser as associações de produtores, 82 pessoas responderam que deveria caber ao Governo; em seguida, aparecem os laboratórios particulares e comerciantes com respectivamente 45 e 44 entrevistados a favor. Os 41 restantes não sabiam quem deveria arcar com a certificação do produto (Figura 8).

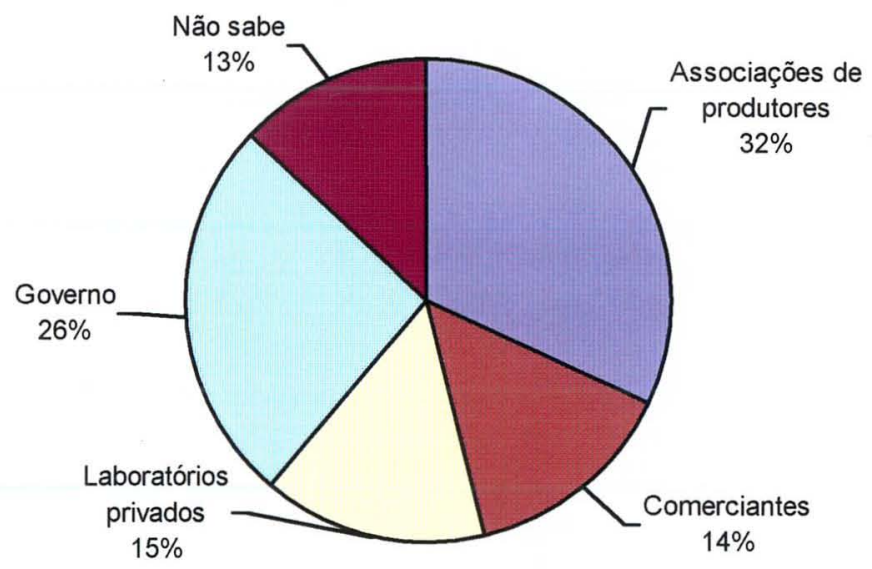

Figura 8 - Emissão de certificado de ausência de agrotóxico. 
O número relativamente baixo de entrevistados que elegeu o governo como órgão certificador serve para dar uma idéia da pouca confiança que os respondentes aparentemente depositam no governo como órgão fiscalizador da segurança do alimento. Esse é um resultado esperado uma vez que as políticas governamentais das últimas décadas têm sido orientadas cada vez mais para a retirada de recursos das instituições públicas, reduzindo a qualidade dos serviços prestados pelas mesmas, dentre os quais o de garantir a segurança dos alimentos. Tal falta de confiança contrasta com a dos consumidores dos países desenvolvidos como, por exemplo, da Europa, onde a confiança no governo em garantir uma oferta segura de alimentos só diminuiu substancialmente depois do surto de incidência de encefalopatia espongiforme bovina (BSE) ou, como é popularmente conhecida, "a doença da vaca louca," nos anos 90, dentre outros acontecimentos já citados no capítulo 1 desta pesquisa e nos estudos de Gil et al. (2000) e de Williams \& Hammitt (2001).

Como exposto anteriormente, acredita-se que um consumidor que manifeste uma atitude mais rigorosa com relação ao uso de agrotóxicos nos processos produtivos esteja mais propenso a pagar um preço mais alto por um produto cultivado sem agrotóxicos. Os resultados deste estudo mostraram que para a maior parte dos consumidores ouvidos $(92 \%)$, todos os agrotóxicos deveriam ser definitivamente proibidos (banidos) ou os que não são seguros deveriam ser proibidos e os restantes deveriam sofrer maiores restrições. É interessante notar que nem sempre um indivíduo a favor de maior rigor no uso de agrotóxicos (92\% dos entrevistados) se dispos a pagar mais por produtos hortifrutícolas sem agrotóxicos (74\%). O Quadro 7 sumariza as principais razões alegadas pelos 81 entrevistados para não pagar mais por HSA. O preço é apontado como principal motivo de recusa por 37\% desses consumidores. Em seguida vêm, com 19\%, os que argumentam que a "qualidade é uma obrigação". 


\begin{tabular}{|l|c|}
\hline \multicolumn{1}{|c|}{ Motivos da recusa } & No. de entrevistados \\
\hline 1. Preço (muito caro) & 30 \\
2. Qualidade é obrigação & 16 \\
3. Não confia no selo de qualidade & 8 \\
4. Outros & 15 \\
5. Não informou & 12 \\
\hline
\end{tabular}

Quadro 7 - Justiticativas apresentadas pelos entrevistados da amostra para não pagar mais por HSA.

Fonte: Dados da pesquisa

\subsection{Estimativas do modelo econométrico}

Para verificar a influência das variáveis especificadas no capítulo de metodologia sobre a disposição a pagar mais por hortifrutícola sem agrotóxicos, foi estimado o modelo lógite da equação (11). A variável dependente disposição a pagar (DAP) representa uma escolha binária, assumindo valor igual a 1 se o consumidor aceita pagar mais por produtos hortifrutícolas sem agrotóxicos e valor zero, caso contrário.

Os resultados da estimação do modelo proposto pelo método de máxima verossimilhança podem ser observados na Tabela 1, juntamente com os efeitos marginais, que permitem inferir a influência das variáveis independentes sobre a disposição de pagar. Esses resultados foram gerados a partir do programa de computador Limdep software package (Greene, 1995). 
Tabela 1. Modelo lógite de disposição a pagar de hortifrutícolas sem agrotóxicos (completo).

\begin{tabular}{lcc}
\hline \multicolumn{1}{c}{ Variável } & Efeito Marginal & Estatística t \\
\hline Constante & $-0,23526$ & $-1,022$ \\
Preço & $-0,15775$ & $-3,142^{* *}$ \\
Teste/governo & $-0,12997$ & $-2,435^{* *}$ \\
Atitude & 0,25907 & $2,916^{* *}$ \\
Grupo de risco & 0,08393 & 1,583 \\
Linha de pobreza & $-0,02791$ & $-0,264$ \\
Idade & 0,00853 & 0,910 \\
Idade2 & $-0,00008$ & $-0,784$ \\
Percepção & 0,05633 & 0,712 \\
Escolaridade & 0,00607 & 0,829 \\
Dieta & $-0,01686$ & $-0,313$ \\
Planejador da refeição & $-0,02916$ & $-0,563$ \\
principal & & \\
Consumo 6 meses & 0,05131 & 0,967 \\
Informação & $-0,01753$ & $-0,289$ \\
Número de observações: 314 & & \\
Multiplicador Lagrange: $31,8375^{* *}$ & \\
* & & \\
\hline
\end{tabular}

denota significância ao nível de 1\%

Ao se analisar o multiplicador Lagrange $(31,83753)$, com 13 graus de liberdade (Tabela 1), constata-se que o modelo é relevante, rejeitando-se a hipótese de 0 mesmo não apresentar poder explicativo para disposição de pagar dos consumidores. Entretanto, das 12 variáveis independentes incluídas, somente o preço, o teste/governo e a atitude foram estatisticamente significativas. Os coeficientes de correlação entre as variáveis (Anexo B) não sugerem a multicolinearidade como uma possível causa para os 
resultados encontrados. Assim sendo, decidiu-se estimar outros modelos em que algumas dessas variáveis não significativas deixaram de ser incluídas. Então, o modelo que melhor representou a disposição a pagar dos consumidores (designado por modelo final) foi o que excluiu as variáveis independentes dieta, planejador principal de refeição, consumo nos últimos seis meses e informação. A Tabela 2 apresenta as variáveis exógenas, com suas respectivas estatísticas descritivas, inseridas nesse modelo.

Tabela 2. Estatísticas descritivas do modelo proposto

\begin{tabular}{lrc}
\hline \multicolumn{1}{c}{ Variável } & Média & Desvio-padrão \\
\hline Preço & 0,3854 & 0,4867 \\
Teste/governo & 0,2707 & 0,4452 \\
Grupo de risco & 0,6815 & 0,4654 \\
Renda familiar per capita & 0,0605 & 0,2387 \\
Idade & 42,9000 & 13,9000 \\
Idade2 & 2040,0000 & 1302,5700 \\
Escolaridade & 8,7300 & 4,1400 \\
Atitude & 0,9236 & 0,2665 \\
Percepção & 0,1369 & 0,3447
\end{tabular}

Fonte: Dados da pesquisa

A razão de verossimilhança com 9 graus de liberdade, do modelo proposto (Tabela 3), apresentou valor de 30,45, constatando a relevância do modelo como um todo na explicação da disposição a pagar HSA dos consumidores. Além das três variáveis do modelo inicial (preço, teste/governo e atitude), a variável grupo de risco também foi estatisticamente significativa neste modelo; as demais, como em todos os outros modelos, não foram estatisticamente diferentes de zero. Os sinais dos coeficientes apresentaram-se, de um modo geral, compatíveis com os esperados. 
Tabela 3. Modelo lógite de disposição a pagar de hortifrutícolas livre de agrotóxicos (proposto).

\begin{tabular}{lcc}
\hline \multicolumn{1}{c}{ Variáveis } & Efeito Marginal & Estatística $t$ \\
\hline Constante & $-0,24874$ & $-1,095$ \\
Preço & $-0,15633$ & $-3,123^{* *}$ \\
Teste/governo & $-0,13173$ & $-2,496^{* *}$ \\
Grupo/risco & 0.08529 & $1,615^{*}$ \\
Atitude & 0.25062 & $2,934^{* *}$ \\
Percepção & 0,05928 & 0,756 \\
Linha de pobreza & $-0,01722$ & $-0,165$ \\
Idade & 0,00903 & 0,966 \\
Idade2 & $-0,00009$ & $-0,854$ \\
Escolaridade & 0,00555 & 0,818
\end{tabular}

Número de observações: 314

Multiplicador Lagrange: $30,4511^{* *}$

Denota significância ao nível de $10 \%$

${ }^{* *}$ denota significância ao nível de $1 \%$

A variável preço teve sinal esperado (negativo), indicando que se o preço é uma das três maiores preocupações do consumidor na hora de comprar hortifrutícolas menor é a probabilidade de ele se dispor a pagar mais por HSA. Fu et al. (1999) também encontraram esse mesmo resultado para consumidores de Taiwan, isto é, os consumidores que consideraram preço um fator importante na decisão de compra de vegetais estão menos dispostos a pagar mais por vegetais com baixo risco de causar doenças cancerígenas. Ott (1990) constatou que entre os consumidores da Geórgia (EUA), um terço dos entrevistados não estava disposto a pagar nenhum prêmio por HSA, e que um pouco menos de $10 \%$ da sua amostra estava disposto a pagar $10 \%$ de prêmio. 
O coeficiente estimado para a variável teste/governo foi negativo, o que significa que a escolha do governo como órgão certificador dos HSA diminui a probabilidade de o consumidor pagar mais por HSA, de $13 \%$. Uma possivel explicação para esse resultado é a de que o consumidor esteja, de alguma forma, atrelando o prêmio a ser pago pelos HSA unicamente ao certificado que o acompanha; assim, sendo o governo o órgão certificador, não haveria motivo para se pagar mais por esses produtos. Nesse caso, o consumidor não está relacionando 'produto sem agrotóxico' com 'oferta menor' e, conseqüentemente, com 'maior preço final' dos produtos hortifrutícolas.

O coeficiente da variável grupo de risco foi positivo e estatisticamente significativo, conforme hipótese do modelo proposto. Desta forma, a existência de pessoas consideradas de risco (crianças, idosos, mulher grávida e indivíduos com alguma doença crônica), na família, afeta positivamente a probabilidade de o consumidor pagar mais por HSA. Lin (1995) também concluiu, em seu estudo, que a segurança do alimento é mais importante para o planejador da refeição principal que, dentre outras características, possui membros da família em situação de risco (idosos, crianças e mulheres grávidas). Resultado semelhante também foi encontrado por Huang et al. (1999) com respeito à disposição de pagar mais por vegetais hidropônicos. No referido estudo, os resultados mostraram que os consumidores que tinham crianças pequenas estavam dispostos a pagar prêmios mais altos pelos produtos hidropônicos.

A correlação positiva entre a presença de crianças na casa e as atitudes de consumidores com relação à segurança dos alimentos foi igualmente reportada por Jussaume \& Higgins (1994), para uma amostra de consumidores do Japão e dos EUA. Em suma, a utilidade do consumidor, nesses casos, não dependeu somente dos atributos dos bens e serviços que ele consumia, como preconiza a teoria neoclássica, mas também da utilidade que o consumo desses bens ou serviços pode trazer a outros membros da sua 
família. Dessa maneira, "o consumo de alimentos seguros vai além do interesse próprio e está associado a preocupações com o bem-estar de outros, particularmente das crianças" "(Senauer ${ }^{19}, 1992$, citado por Jussaume \& Higgins, 1998, p. 397). Esses últimos consideram "plausível supor que as percepções dos adultos com relação a muitos riscos aumentam quando eles se tornam pais". Para eles, "qualquer tentativa de explicar a expansão das preocupações com segurança dos alimentos deve reconhecer que os comportamentos e atitudes podem refletir preocupação com o bem-estar de terceiros (Jussaume \& Higgins, 1998, p. 397).

Como era de se esperar, a variável atitude foi fortemente significativa na explicação da intenção dos entrevistados de pagar mais por HSA. Praticamente $92 \%$ da amostra se mostrou a favor de ações reguladoras para os agrotóxicos. Assim, ser favorável ao banimento total ou parcial dos agrotóxicos (variável atitude igual a 1) aumenta em $25 \%$ probabilidade de preferência do consumidor por HSA.

Contrariamente ao esperado, os resultados do modelo mostraram que a variável percepção (=1 quando 'produtos cultivados com agrotóxicos' foi apontado como um dos três principais itens levados em conta no momento da compra de hortifrutícolas), embora tenha apresentado sinal compatível com o esperado, não foi estatisticamente diferente de zero. Isso significa que a probabilidade de pagar mais por HSA aumenta com a atitude mas não é influenciada pela percepção que os consumidores têm dos produtos com resíduos de agrotóxicos. Entretanto, é possível que o critério adotado para testar a percepção dos consumidores não tenha sido adequado para as condições brasileiras atuais uma vez que pouquíssimos são os estabelecimentos de varejo que oferecem, hoje, ao consumidor, a opção de poder adquirir 'produtos cultivados sem agrotóxicos'. O espaço destinado a esses produtos, mesmo nos grandes supermercados da cidade de Piracicaba, local da pesquisa, é extremamente reduzido, podendo passar facilmente despercebido pelos consumidores. Assim, considerar esse um dos três itens mais importantes no "momento da compra de hortifrutícolas" (o que, para

\footnotetext{
${ }^{19}$ SENAUER, B. Consumer food safety concerns. Cereal Foods World, v.37, p.298-303, 1992.
} 
este estudo significaria ter percepção do risco que produtos com resíduos de agrotóxicos podem causar à saúde) pode não ter sentido mesmo para pessoas que tenham conhecimento do problema.

As demais variáveis (idade, idade2 e escolaridade), embora com sinais esperados (exceto linha de pobreza), não foram estatisticamente diferentes de zero, resultados também encontrados para a amostra de consumidores de Taiwan, do estudo de Fu et al. (1999). É interessante lembrar que, embora não significativas na decisão de pagar mais por HSA, essas variáveis podem ser importantes na decisão sobre as quantias dos prêmios que os consumidores estão dispostos a pagar por HSA, como Haung et al. (1999) mostraram em seu estudo. Entretanto, essa hipótese não pôde ser testada por este estudo. 


\section{CONCLUSÕES}

Os agrotóxicos e as drogas que respaldam a produção em massa de alimentos suscitam novos cuidados. Resíduos de agrotóxicos estão presentes na maioria dos hortifrutícolas cultivados de forma tradicional. Embora os testes realizados identifiquem estes alimentos como seguros situando-os dentro da margem de segurança, o alarme acerca dos efeitos dos agrotóxicos continua intenso.

A preocupação do público com questões de segurança dos alimentos, particularmente resíduos de agrotóxicos, vêm sendo documentada na literatura de diversos países. Destacam-se, neste ponto, os estudos envolvendo os consumidores europeus e norte-americanos. Nos países em desenvolvimento, e inclusive no Brasil, são escassos estudos desta natureza. Despontam apenas trabalhos de natureza descritiva. Poucos pesquisadores têm focado na análise de fatores que podem afetar o comportamento dos consumidores quanto à segurança do alimento.

Embora tenham crescido substancialmente no mercado, nos últimos anos, os produtos sem agrotóxicos ainda representam um segmento muito pequeno do mercado de alimentos no mundo. Desta forma, constituem-se num mercado pequeno $\mathrm{e}$ conseqüentemente, os produtos não estão largamente distribuídos no comércio varejista. Por essa razão, o método de valoração contingente (MVC), empregado para avaliar monetariamente os bens não transacionados no mercado (recursos naturais), tem sido largamente utilizado para estudar a disposição de pagar por segurança do alimento particularmente no que se refere à presença de resíduos de agrotóxicos. 
O presente trabalho teve como ênfase analisar o comportamento dos consumidores quanto a segurança dos hortifrutícolas in natura e sua disposição de pagar preços mais altos por estes produtos, relativamente aos convencionais (produzidos com agrotóxicos). Foram entrevistados, aleatoriamente, 314 consumidores em diversos pontos de comercialização de hortifrutícolas, durante os meses de abril e maio de 2002, na cidade de Piracicaba, no Estado de São Paulo.

Vale a pena mencionar que este estudo possivelmente esteja sujeito a natureza da coleta dos dados. Pesquisas desta natureza esbarram em complicações porque alternativas disponíveis aos hortifrutícolas produzidos convencionalmente podem não estar disponíveis em todos os mercados dos bairros pesquisados. Ainda, de modo geral, em alguns supermercados da cidade de Piracicaba, e do país em geral, o espaço nas gôndolas destinado a esses produtos é extremamente reduzido, podendo passar facilmente despercebidos pelos consumidores. Outra complicação está atrelada à natureza dificil da extração de julgamentos de riscos subjetivos e da relativa segurança do alimento. Será que as respostas dos consumidores refletem seus medos mas não suas intenções de compra?

Os resultados obtidos foram importantes e elucidativos para avaliar os diversos fatores que influenciam os consumidores no tocante a segurança dos alimentos. Mais de dois terços dos consumidores entrevistados foram do sexo feminino. Isto era esperado porque tem-se sugerido na literatura, que as mulheres são mais preocupadas com a saúde humana do que os homens. A idade média ficou em torno de 43 anos e o tamanho da família, de quatro pessoas. No geral, apesar de aleatória, a amostra foi caracterizada por indivíduos com alta renda e alto grau de instrução. A renda média familiar per capita mensal, em valores de abril/maio de 2002, foi da ordem de R\$ 1.638,00; comparando-se com o valor geralmente usado para delimitar a linha de pobreza da população (de meio salário mínimo - $\mathrm{R} \$ 90,00$ na época do levantamento da pesquisa), conclui-se ser a mesma extremamente alta. Apenas $6 \%$ da amostra apresentaram renda familiar per capita mensal igual ou inferior a $\mathrm{R} \$ 90,00$. Também a 
média do número de anos de escolaridade da amostra foi alta ( 8,7 anos) se comparada com as respectivas médias estadual e nacional, de 7,1 e 6,1 anos.

As preferências dos consumidores por atributos de segurança do alimento são latentes e serão expressas somente quando divulgadas com a ocorrência de casos alarmantes como do Alar nas maças, "vaca louca" etc. (Baker, 1998). No Brasil, começam a ser divulgados incidentes de contaminação de moradores e do meio ambiente, como, por exemplo, o da fabrica de pesticida da Shell em Paulínia/SP. Nesta pesquisa, a mídia, de um modo geral, foi citada como uma das principais fontes de informação a respeito da presença de resíduos de agrotóxicos nos alimentos. Aos veículos de comunicação cabem a responsabilidade da divulgação e informação para a sociedade no tocante à qualidade dos alimentos e a conseqüente redução dos riscos à saúde.

Quanto ao impacto estimado das variáveis socioeconômicas e demográficas sobre a disposição de pagar mais por HSA, concluiu-se que foram significativas estatisticamente somente as variáveis explicativas: preço, teste/governo, grupo de risco e atitude. Se o preço é uma das três maiores preocupações do consumidor na hora de comprar hortifrutícolas, menor é a probabilidade de ele se dispor a pagar mais por HSA. O coeficiente estimado para a variável teste/governo foi negativo o que significa que a escolha do governo como órgão certificador dos HSA embora denote confiança no governo, diminui a probabilidade de o consumidor pagar mais por HSA. O coeficiente da variável grupo de risco foi positivo conforme hipótese do modelo proposto, ou seja, a existência de pessoas consideradas de risco, na família, afeta positivamente a probabilidade de o consumidor pagar mais por HSA. Os resultados mostraram que $63,5 \%$ dos entrevistados apresentavam em sua família pelo menos uma pessoa integrante desse grupo. Finalmente, a variável que buscou refletir o grau de rigor dos consumidores quanto ao tratamento que deve ser dado aos agrotóxicos (atitude), foi fortemente significativa na explicação da intenção dos entrevistados de pagar mais por HSA. Em outras palavras, quanto mais rigoroso o consumidor, relativamente às políticas voltadas aos agrotóxicos, maior a probabilidade de ele se dispor a pagar mais por HSA. A 
percepção, embora com sinal esperado, não foi tampouco estatisticamente diferente de zero. Apesar de a pesquisa realizada pela empresa Feedback, nas principais capitais brasileiras, ter observado que o interesse pela segurança do alimento aumenta com a idade, com a renda e com o nível educacional, neste estudo essas variáveis não foram estatisticamente significativas.

O estudo revelou ainda que $92 \%$ da amostra se mostrou a favor de ações reguladoras para os agrotóxicos, evidenciando uma preocupação com a qualidade dos alimentos, o que já ocorre nos países desenvolvidos. Estas nações impõem rígidos padrões de qualidade a importações de alimentos. Para este novo comportamento dos consumidores empresas e agentes governamentais devem estar atentos a acompanhar essas mudanças para satisfazer as exigências e as preferências, não só do consumidor interno, mas, também do externo.

Ao governo cabe atuar sobre a assimetria de informação existente no mercado dos alimentos. Assim como a qualidade, os problemas relacionados com resíduos de agrotóxicos nos alimentos nem sempre podem ser visualizados externamente. $\mathrm{O}$ problema ganha maiores proporções à medida que Brasil não possui, atualmente, um programa nacional de monitoramento de resíduos de pesticidas em alimentos (Caldas \& Souza, 2000). Assim é imprescindível, por parte do poder público, a formulação de políticas baseadas em níveis máximos de tolerâncias a agrotóxicos em alimentos crus e processados. Ainda, as autoridades devem agir em todos os elos da cadeia produtiva fazendo com que os alimentos servidos na mesa dos brasileiros, ao serem comercializados, exibam um selo de controle de qualidade com todas as informações e origem do produto.

Atualmente, um segmento de mercado que começa ganhar proporções é o da produção para o bem-estar das pessoas ("qualidade de vida") e não para aumentar a escala da produção. É o caso dos alimentos. Julga-se cada vez mais necessário saber o que se come, de que forma e procedência é esta comida. Desta forma, é importante obter maiores informações sobre a relação entre características individuais e a importância 
percebida sobre a segurança do alimento. Futuras pesquisas também devem avaliar outras preferências por atributos importantes no consumo, como os relacionados aos aspectos nutricionais, saúde (gordura, sal e glicose) e aos aspectos ambientais, uma preocupação cada vez mais presente nas sociedades.

O aumento da população mundial e a crescente pressão sobre a demanda de alimentos faz surgir, no admirável mundo da engenharia genética como da pesquisa agropecuária, uma enorme necessidade de produção de alimentos. Contudo, é necessário que todo este avanço tecnológico esteja associado a uma produção que garanta o bemestar das pessoas, começando pela segurança dos alimentos produzidos, seja através de uma agricultura sustentável ou processados em laboratórios. A prosperidade de um país também é garantida quando ele é capaz de produzir os alimentos necessários para nutrir seus habitantes, mas sem que isso implique em sérios, e principalmente desconhecidos, riscos de saúde pública.

O crescente interesse pela segurança do alimento é aumentado ainda mais com a introdução dos alimentos geneticamente modificados sem se saber as conseqüências que os mesmos terão sobre a saúde humana, o meio ambiente e a vida animal. Isto suscita, não apenas novas pesquisas sobre a segurança dos alimentos, mas também fica explícito um retorno a Primavera Silenciosa de Rachel Carson. 
ANEXOS 
ANEXO A - FORMULÁRIO PARA ENTREVISTA

\begin{tabular}{|c|c|}
\hline $\begin{array}{l}\text { 1. Na sua casa, vocês costumam comer } \\
\text { verduras, legumes e frutas frescas? }\end{array}$ & $\begin{array}{r}\text { ( ) NÃO ( ) SIM. Com que freqüência? } \\
\qquad \begin{array}{l}(\text { ) Todo dia } \\
(\text { ) Uma vezez/semana }\end{array}\end{array}$ \\
\hline $\begin{array}{l}\text { 2. É o(a) Sr.(a) quem decide o que a } \\
\text { família deve comer? }\end{array}$ & ( ) NÃO ( ) SIM \\
\hline $\begin{array}{l}\text { 3. O(a) senhor(a) mora nessas } \\
\text { redondezas? }\end{array}$ & ( ) NÃO \\
\hline $\begin{array}{l}\text { 4. Dos itens listados ao lado, assinale } \\
\text { três que o(a) Sr.(a) leva em } \\
\text { consideração na compra de } \\
\text { verduras. }\end{array}$ & $\begin{array}{l}\text { ( ) Valor alimentar (vitaminas, sais minerais, } \\
\text { calorias, etc.) } \\
\text { ( ) Cor, manchas, danos superficiais, } \\
\text { tamanho } \\
\left(\begin{array}{l}\text { ( ) Origem dos produtos (fazenda, sítio, } \\
\text { chácara onde foi produzido) }\end{array}\right. \\
\text { ( ) Produtos cultivados com agrotóxicos } \\
\text { ( ) Frescor (se são recém-colhidos, se estão } \\
\text { dentro da validade) } \\
\text { ( ) Sabor, cheiro característico e textura } \\
\text { (consistência) do alimento } \\
\text { ( ) Local de venda (feira livres, } \\
\text { supermercados, quitandas, etc) } \\
\text { ( ) Praticidade (processamento mínimo: } \\
\text { cortado/picado e selecionado) } \\
\text { ( ) Preço } \\
\text { ( ) Uso de conservantes e/ou aditivos } \\
\text { quimicos }\end{array}$ \\
\hline $\begin{array}{l}\text { 5. O Sr.(a) sabe que as verduras podem } \\
\text { estar contaminadas com resíduos de } \\
\text { agrotóxicos? }\end{array}$ & ( ) SIM. Como você sabe? \\
\hline
\end{tabular}




\begin{tabular}{|c|c|}
\hline $\begin{array}{l}\text { 6. Para o(a) Sr.(a), seria importante que } \\
\text { os produtos fossem testados e } \\
\text { apresentassem um selo de garantia } \\
\text { de que não contém agrotóxicos? }\end{array}$ & ( ) NÃO \\
\hline $\begin{array}{l}\text { 7. Se um selo garantindo a ausência de } \\
\text { agrotóxico for fornecido para } \\
\text { verduras, legumes e frutas frescas, } \\
\text { quem o(a) Sr.(a) acha que deveriam } \\
\text { fornecê-lo? }\end{array}$ & $\begin{array}{l}\text { ( ) o governo } \\
\text { ( ) os laboratórios particulares independentes } \\
\text { ( ) quem vende (supermercados, quitandas, } \\
\text { etc. } \\
(\quad \text { ) as associações de produtores } \\
\text { ( ) não sei }\end{array}$ \\
\hline $\begin{array}{l}\text { 8. O Sr.(a) estaria disposto(a) a pagar } \\
\text { mais por uma verdura que } \\
\text { apresentasse esse selo? }\end{array}$ & ( ) NÃO. Por que? ( ) SIM \\
\hline $\begin{array}{l}\text { 9. Qual é sua opinião com relação aos } \\
\text { agrotóxicos? }\end{array}$ & $\begin{array}{l}\text { ( ) todos deveriam ser proibidos } \\
\text { definitivamente; } \\
\text { ( ) os que não são seguros deveriam ser } \\
\text { proibidos definitivamente e os restantes } \\
\text { deveriam sofrer maiores restrições } \\
\text { ( ) nenhuma delas }\end{array}$ \\
\hline $\begin{array}{l}\text { 10. Na sua opinião, o(a) Sr.(a) considera } \\
\text { o risco de ser assaltado: }\end{array}$ & $\begin{array}{l}\text { ( ) Maior do que o risco de comer verduras } \\
\text { contaminadas com agrotóxicos } \\
\text { ( ) Menor do que o risco de comer verduras } \\
\text { contaminadas com agrotóxicos } \\
\text { ( ) Igual ao risco de comer verduras } \\
\text { contaminadas com agrotóxicos }\end{array}$ \\
\hline $\begin{array}{l}\text { 11. Nos últimos } 6 \text { meses, o consumo de } \\
\text { verduras na sua casa aumentou? }\end{array}$ & ( ) NÃO \\
\hline
\end{tabular}




\begin{tabular}{|c|c|c|}
\hline $\begin{array}{l}\text { 12. Na sua casa, alguém faz regime para } \\
\text { emagrecer? }\end{array}$ & ( ) NÃO & ) SIM \\
\hline $\begin{array}{l}\text { 13. Para o Sr.(a) um produto cultivado } \\
\text { sem agrotóxico, é chamado de: }\end{array}$ & $\begin{array}{l}\text { ( ) "Light" } \\
(\text { )"Diet" } \\
(\text { ) Hidropônico } \\
\text { ( ) Outro }\end{array}$ & $\begin{array}{l}\text { ) Agroecológico } \\
\text { ) Natural } \\
\text { ) Orgânico } \\
\text { ) Não sei }\end{array}$ \\
\hline $\begin{array}{l}\text { 14. O(a) Sr.(a) usa algum tipo de } \\
\text { veneno para ratos, baratas e outros } \\
\text { insetos na sua casa? (ex.: hortas, } \\
\text { jardins, vasos de plantas, } \\
\text { dedetização) }\end{array}$ & ( ) NÃO & ) SIM \\
\hline $\begin{array}{l}\text { 15. Quantas pessoas moram na sua } \\
\text { casa? }\end{array}$ & (núme & ero de pessoas) \\
\hline 16. Na sua casa tem: & $\left\{\begin{array}{l}\text { ( ) Gestante } \\
\text { ( ) Idoso (com mais de } \\
(\text { ) Crianças com } 12 \text { an } \\
(\text { ) Outros }\end{array}\right.$ & 65 anos de idade) \\
\hline $\begin{array}{l}\text { 17. Existe alguém na sua casa com } \\
\text { alguma doença crônica grave? }\end{array}$ & ( ) NÃO & ) SIM \\
\hline $\begin{array}{l}\text { 18. Até que ano o(a) Sr.(a) cursou a } \\
\text { escola? }\end{array}$ & $\begin{array}{l}\text { Não freqüentou a escola } \\
1^{\circ} \cdot \text { grau } \\
2^{\circ} \cdot \text { grau } \\
\text { Graduação } \\
\text { Pós-Graduação }\end{array}$ & $\begin{array}{l}0 \\
12345678 \\
123 \\
123456 \\
12345678910\end{array}$ \\
\hline $\begin{array}{l}\text { 19. Trabalha fora? (seja tempo integral } \\
\text { ou parcial) }\end{array}$ & ( ) NÃO & ) SIM \\
\hline
\end{tabular}




\begin{tabular}{|l|l|}
\hline 20. Qual a sua ocupação? & Descrever: \\
\hline $\begin{array}{c}\text { 21. O(a) Sr.(a) poderia me dizer qual a } \\
\text { renda total mensal da sua família? }\end{array}$ & $\mathrm{R} \$$ \\
\hline 22. Qual a sua idade? & anos \\
\hline
\end{tabular}

Muito obrigado pela sua colaboração !!!

Anotar a cor e sexo do entrevistado:

Entrevistador :

Quest./ $\mathrm{n}^{\mathrm{O}}$

Local:

Data:

12002

Hora:

Receptividade do(a) entrevistado(a): ( ) Ótima ( ) Boa ( ) Regular ( ) Ruim 

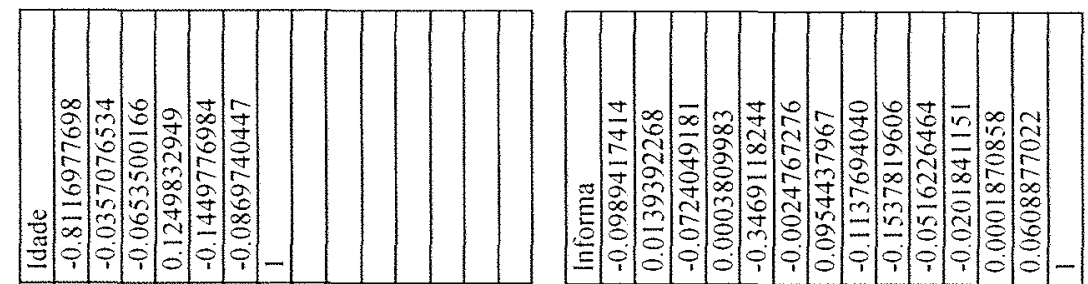

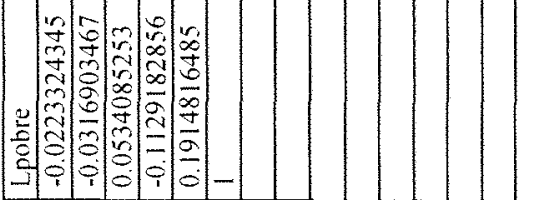
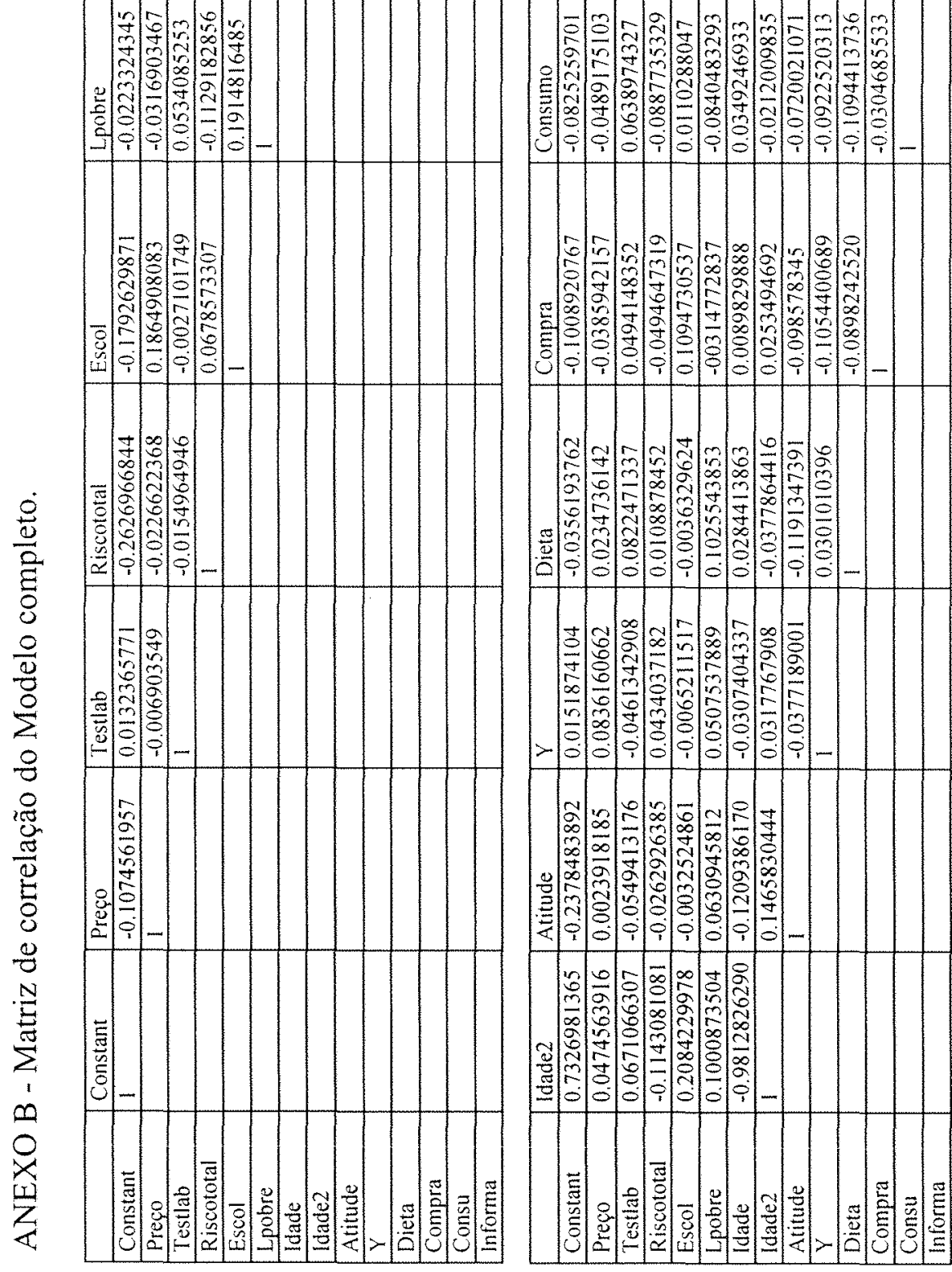


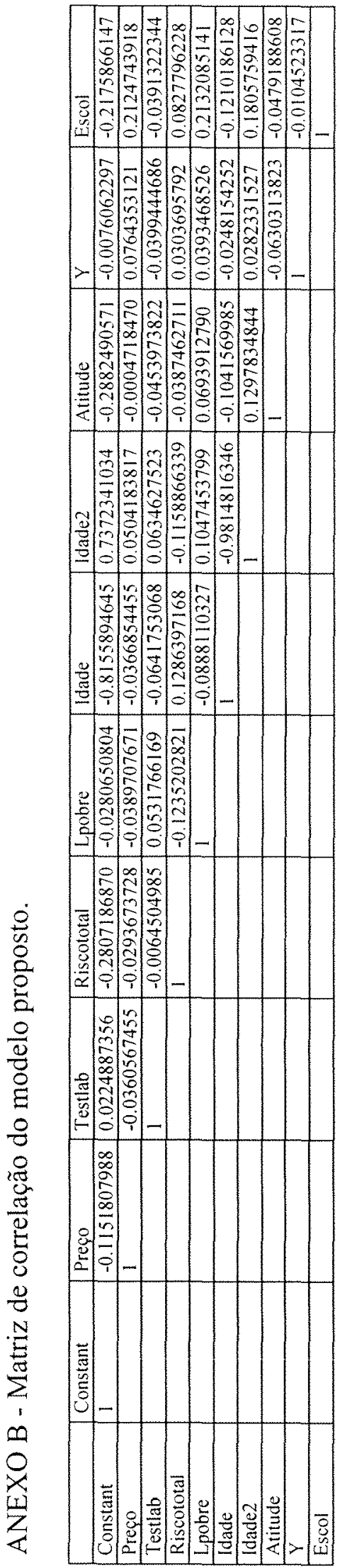




\section{REFERÊNCIAS BIBLIOGRÁFICAS}

AGUIRRE, A.; FARIA, D.M.C. de. Avaliação contingente de investimentos ambientais: um estudo de caso. Estudos Econômicos, v.26, n.1, p.58-109, 1996.

AKERLOF, G.A. The market for "lemons": quality uncertainty and the mechanism. Quarterly Journal of Economics, v.84, n.3, p.488-500, 1970.

AKGUNGNOR-S.; MIRAN-B.; ABAY-C. Consumer willingness to pay for food safety labels in urban Turkey: a case study of pesticide residues in tomatoes. Journal of International Food \& Agribusiness Marketing, v.12, n.1, p.91-107, 2001.

ARAÚJO, A.; NOGUEIRA, D.P.; AUGUSTO, L.G.S. Impacto dos praguicidas na saúde: estudo da cultura de tomate. Revista de Saúde Pública, v.34, n.3, p.309-313, 2000.

BAKER, G.A. Strategic implications of consumer food safety preferences. International Food and Agribusiness Management Review, v.1, n.4, p.451-463, 1998.

BELLUZO JÚNIOR, W. Valoração de bens públicos: o método de avaliação contingente. São Paulo, 1995. 151p. Dissertação (M.S.) - Faculdade de Economia, Administração e Contabilidade, Universidade de São Paulo.

BYRNE, P.J.; BACON, R.J.; TOENSMEYER, U.C. Pesticide residue concerns and shopping location likelihood. Agribusiness, v.10, n.6, p.491-501, 1994. 
BRUGNARO, C. Valor atribuído pela população às matas ciliares da Bacia do Rio Corumbataí. Piracicaba, 2000. 146p. Tese (Doutorado) - Escola Superior de Agricultura "Luiz de Queiroz", Universidade de São Paulo.

CALDAS, E.D.; SOUZA, L.C.K.R. Avaliação de risco crônico da ingestão de resíduos de pesticidas na dieta brasileira. Revista de Saúde Pública, v.34, n.5, p.529-537, 2000.

CARSOAN, R. Primavera silenciosa. São Paulo: Melhoramentos,1962. 305p.

CERRI, C. O sabor do século 21. Globo Rural, n.188, p.47-53, 2001.

CERVEIRA, R.; CASTRO, M.C. Consumidores de produtos orgânicos na cidade de São Paulo: características de um padrão de consumo. Informações Econômicas, v.29, n.12, p. $7-20,1999$.

COMÉRCIO de agrotóxico cresce $21,6 \%$. Folha de São Paulo. Folha Ciência, São Paulo, 20 jun. 2002. p.A19.

COX, C. Inert ingredients in pesticides: who's keeping secrets? Journal of Pesticide Reform, v.19, n.3, p.2-7,1999.

DAY, K.A.; KUHN, A.B.; VANDEMAN, A.M. Measuring the food safety risk of pesticides. In: CASWELL, J.A. Valuing food safety and nutrition. Boulder: Westview Press, 1995. Chap.18, p.393-410.

DOSMAN, D.M.; ADAMOWICZ, W.L.; HRUDEY, S.E. Socioeconomic determinants of health: and food safety-related risk perceptions. Risk Analysis, v.21, n.2, p.307317,2001 .

ENGEL, J.F.; BLACKWELL, R.D.; MINARD, P.W. Comportamento do consumidor. Rio de Janeiro: LTC, 1999. 641p. 
FAZIO, G.; FURQUIM, M.F.; KASSOUF, A.L. Preocupações dos consumidores com qualidade de alimentos. Preços Agrícolas, v.11, n.123, p.9-12, 1997.

FU, T.-T.; LIU, J.-T.; HAMMITT, J.K. Consumer willingnes to pay for low-pesticide fresh produce in Taiwan. Journal of Agricultural Economics, v.50, n.2, p.220-233, 1999.

GARCIA, E. Segurança e saúde no trabalho rural com agrotóxicos: contribuições para uma abordagem mais abrangente. São Paulo, 1996. 231p. Tese (Doutorado) Faculdade de Saúde Pública, Universidade de São Paulo.

GIL, J.M.; GRACIA, A.; SÁNCHEZ, M. Market segmentation and willingness to pay for organic products in Spain. International Food and Agribusiness Management Review, v.3, n.2, p.207-226, 2000.

GREENE, W.H. LIMDEP: version 7.0. New York: Econometric Software Inc., 1995. $850 \mathrm{p}$.

GREENE, W.H. Econometric analysis. 3.ed. New Jersey: Prentice-Hall, 1997. 1075p.

GORENSTEIN, O. Uma abordagem sobre resíduos de agrotóxicos em alimentos frescos Informações Econômicas, v.30, n.3, p.37-40, 2000.

HANEMANN, W.M. Welfare evaluations in contingent experiments with discrete response data. American Journal of Agricultural Economics, v.66, n.3, p.332-341, 1984.

HAMMITT, J. K. Consumer willingness to pay to avoid pesticide residues. Statistica Sinica, v.3, n.2, p.351-366, 1993.

HUANG, C.L.; MISRA, S.; OTT, S.L. Modeling consumer risk perception and choice behavior: the case of chemical residues in fresh produce. In: MAYER, R.N. (Ed.). Enhancing consumer choice. Columbia: American Council on Consumer Interests, 1991. Chap.5, p.49-58. 
HUANG, C.L.; KAN, K.; FU, T.-T. Consumer willingness to pay for food safety in Taiwan: a binary-ordinal probit model of analysis. Journal of Consumer Affairs, v.33, n.1, p.76-91, 1999.

INSTITUTO BRASILEIRO DE GEOGRAFIA E ESTATÍSTICA. Pesquisa nacional por amostra de domicílios (compact disk). Rio de Janeiro: IBGE, 1998.

JUDGE, G.G.; HILL, R.C.; GRIFFIHS, W.E.; LUTKEPPOHL, LEE T. Introduction to the theory and practice of econometrics. 2.ed. New York: John Wiley \& Sons, 1988. 1024 p.

JUSSAUME, R.A.; HIGGINS, L. Attitudes towards food safety and the environment: a comparison of consumers in Japan and the U.S. Rural Sociology, v.63, n.3, p.394$411,1998$.

LAI, Y.; FLORKOWSKI, W.; HUANG, C.; BRUCKNER, B.; SCHONOF, I. Consumer willingness to pay for improved attributes of fresh vegetables: a comparison between Atlanta and Berlin. In: AMERICAN AGRICULTURAL ECONOMICS ASSOCIATION ANNUAL MEETING, 1997. http://agecon.lib.umn.edu (24 Apr. 2002)

LANCASTER, K. Consumer demand: a new approach. New York: Columbia University Press, 1971. 177p.

LANDRIGAN, P.J. Pesticides and Polychlorinated Biphenyls (PCBs): a analysis of the evidence that they impair children's neurobehavioral development. Molecular Genetics and Metabolism, v.73, n.1, p.11-17, 2001.

LE COUTEUR, D.G.; MCLEAN, J.; TAYLOR, M.; WOODHAM, B.L.; BOARD, P.G. Pesticides and Parkinson's disease. Biomedicine \& Pharmacotherapy, v.53, n.3, p.122-130, 1999. 
LEITE, E. Produtos orgânicos ambientalmente prósperos. Agroanalysis, v.1, n.1, p.58$62,1999$.

LEVY, C. Agrotóxico mata mais no país. Estado de São Paulo. Suplemento Agrícola, São Paulo, 06 out. 1999. p.G-12.

LIN, C.-T.J. Demographic and socioeconomic influences on the importance of food safety in food shopping. Agricultural and Resource Economics Review, v.24, n.2, p.190-198, Oct.1995.

LOPES, J. Poluentes ameaçam megareserva de água. Folha de São Paulo. Folha Ciência, São Paulo, 21 ago. 2002. p.A-10.

MADDALA, G.S. Limited-dependent and qualitative variables in economectris. Cambridge: Cambridge University Press, 1990. 401p.

MARCONI, M.A.; LAKATOS, E.M. Técnicas de pesquisa: planejamento e execução de pesquisas, amostragens e técnicas de pesquisa, elaboração, análise e interpretação de dados. São Paulo: Atlas, 1990.231p.

MITCHELL, R.C.; CARSON, R.T. Using surveys to value public goods: the contingent valuation method. Washington: Resources for the Future, 1989. 463p.

MOTA, R.S. da. Manual para valoração econômica de recursos ambientais. Brasília: Ministério do Meio Ambiente, dos Recursos Hídricos e da Amazônia Legal, 1988. $216 \mathrm{p}$.

NEVES, E.M.; RODRIGUES, L.; DAYOUB, M.; DRAGONE, D.S. Defensivos agrícolas no Brasil: estratégias empresariais, evolução no consumo e demanda relativa. Piracicaba: ESALQ, 2002. 23p. (Relatório de pesquisa)

OLIVIERA, S.L. Tratado de metodología científica. São Paulo: Pioneira, 320p. 1988. 
OTT, S.L. Super market shopper's pesticide concerns and willingness to purchase certified pesticide residue-free fresh produce. Agribusiness, v.6, n.6, p.593-602, 1990.

PEREIRA,V.M. O recente processo migratório brasileiro e seus determinantes. Piracicaba, 2000. 62p. Dissertação (Mestrado) - Escola Superior de Agricultura "Luiz de Queiroz", Universidade de São Paulo.

PESQUISA sobre o consumo de alimentos. Superinteressante, supl., jul./ago. 1991. (Pesquisa encomendada à Feedback Serviços de Pesquisa)

PESSANHA, B.M.R.; MENEZES, F.A.F. A questão dos agrotóxicos. Agroanalysis, v.9, n.9, p. 2-22, 1985.

PIMENTEL, D.; ACQUAY, H.; BILTONEN, M.; RICE, P.; SILVA, M.; NELSON, J.; LIPNER, V.; GIORDANO, S.; HOROWITZ, A. Assessment of environmental and economic impacts of pesticida use. In: PIMENTEL, D.; LEHMAN, H. (Ed.). The pesticide question: environment, economics and ethics. New York: Chapman \& Hall, 1993. p.47-84.

PIRACICABA. Secretaria Municipal. Divisão de Banco de Dados Socioeconômicos. Perfil socioeconômico do Município de Piracicaba - 1995. Piracicaba: SEMUPLAN, 1996. 60p.

PRIMAVESI, A. Alimentação no século XXI. Agroecologia, v.1, n.3, p.5-6, 2000.

PRIYADARSHI, A; KHUDER, S.A; SCHAUB, E.A.; PRIYADARSHI, S.S. Environmental risk factors and parkinson's disease: a metaanalysis. Environmental Research, v.86, n.2, p.122-127, 2001.

RIBEIRO, F.L. Avaliação contingente de danos ambientais: o caso do rio Meia-Ponte em Goiânia-GO. Viçosa, 1998. 80p. Dissertação (Mestrado) - Universidade Federal de Viçosa. 
SACHS, C.; BLAIR, D.; RICHTER, C. Consumer pesticide concerns: a 1965 and 1984 comparison. The Journal of Consumer Affairs, v.21, n.1, p.96-107, 1987.

SPERS, E.E. Preferência do consumidor por atributos de segurança: aplicação de Conjoint Analysis. Piracicaba, 1999. 108p. Dissertação (Mestrado) - Escola Superior de Agricultura "Luiz de Queiroz", Universidade de São Paulo.

SPERS, E.E.; KASSOUF, A.L. A abertura de mercado e a preocupação com a segurança dos alimentos. Higiene Alimentar, v.10, n.46, p.16-26, 1996.

USO incorreto afeta a produção. Produtor Parmalat, v.6, n.62, p.30-33, abr. 2002.

UNDERHILL, S.E.; FIGUEROA, E.E. Consumer preferences for non-conventionally grown produce. Journal of Food Distribution Research, v.27, n.2, p.56-66, 1996.

WEAVER, R.D.; EVANS, D.J.; LULOFF, A.E. Pesticide use in tomato production: consumer and willingness-to-pay. Agribusiness, v.8, n.2, p.131-142, 1992.

WILES, R.; DAVIES, K; CAMPBELL, C. Overexposed: organophosphate insecticides in children's food, environmental. Washington, 1998. http://ewg.org/pub/home/reports/ops/oppress.html (24 Apr. 2002)

WILLIAMS, P.R.D.; HAMMITT, J.K. Perceived risks of conventional and organic produce: pesticides, pathogens, and natural toxins. Risk Analysis, v.21, n.2, p.319$330,2001$.

ZADOKS, J.C.; WAIBEL, H. From pesticide to genetically modified plants: history, economicas and politics. Netherlands Journal of Agricultural Science, v.48, p.125-149, 2000. 